\title{
Pharmacological development of target-specific delocalized lipophilic cation- functionalized carboranes for cancer therapy
}

Eirini D. Tseligka, ${ }^{1}$ Aikaterini Rova, ${ }^{1}$ Elsa P. Amanatiadou, ${ }^{1}$ Gianpiero Calabrese, ${ }^{2}$ John Tsibouklis, ${ }^{3}$ Dimitrios G. Fatouros, ${ }^{4}$ and Ioannis S. Vizirianakis ${ }^{1,5^{*}}$

${ }^{1}$ Department of Pharmacology, School of Pharmacy, Aristotle University of Thessaloniki, GR-54124 Thessaloniki, Greece

${ }^{2}$ School of Pharmacy and Chemistry, Kingston University, Kingston-upon Thames, KT1 2EE, UK

${ }^{3}$ School of Pharmacy and Biomedical Sciences, University of Portsmouth, Portsmouth, PO1 2DT, UK

${ }^{4}$ Department of Pharmaceutical Technology, School of Pharmacy, Aristotle University of Thessaloniki, GR-54124 Thessaloniki, Greece

${ }^{5}$ Department of Life and Health Sciences, University of Nicosia, 1700 Nicosia, Cyprus

Running title: DLC-functionalized carboranes for cancer therapy

*Corresponding author: Ioannis S. Vizirianakis, Ph.D., Department of Pharmacology, School of Pharmacy, Aristotle University of Thessaloniki, GR-54124 Thessaloniki, Greece.e-mail: ivizir@pharm.auth.gr 


\begin{abstract}
PURPOSE: Tumor cell heterogeneity and microenvironment represent major hindering factors in the clinical setting toward achieving the desired selectivity and specificity to malignant tissues for molecularly targeted cancer therapeutics. In this study, the cellular and molecular evaluation of several delocalized lipophilic cation (DLC)-functionalized carborane compounds as innovative anticancer agents is presented.
\end{abstract}

METHODS: The anticancer potential assessment of the DLC-carboranes was performed in established normal (MRC-5, Vero), cancer (U-87 MG, HSC-3) and primary glioblastoma cancer stem $\left(\mathrm{EGFR}^{\mathrm{pos}}, \mathrm{EGFR}^{\text {neg }}\right)$ cultures. Moreover, the molecular mechanism of action underlying their pharmacological response is also analyzed.

RESULTS: The pharmacological anticancer profile of DLC-functionalized carboranes is characterized by: a) a marked in vitro selectivity, due to lower concentration range needed (ca. 10 fold) to exert their cell growth-arrest effect on U$87 \mathrm{MG}$ and HSC-3, as compared with that on MRC-5, Vero; b) a similar selective growth inhibition behavior towards $\mathrm{EGFR}^{\text {pos }}$ and $\mathrm{EGFR}^{\text {neg }}$ cultures $(>10$ fold difference in potency) without, however, the activation of apoptosis in cultures; c) notably, in marked contrast to cancer cells, normal cells are capable of recapitulating their full proliferation potential following exposure to DLC-carboranes; and, d) such pharmacological effects of DLC-carboranes has been unveiled to be elicited at the molecular level through activation of the p53/p21 axis.

CONCLUSIONS: Overall, the data presented in this work indicates the potential of the DLC-functionalized carboranes to act as new selective anticancer therapeutics that 
may be used autonomously or in therapies involving radiation with thermal neutrons. Importantly, such bifunctional capacity may be beneficial in cancer therapy.

KEY WORDS: DLC-carboranes; normal cells; cancer cells; anticancer therapeutics; p53/p21 axis.

\section{ABBREVIATIONS}

BNCT: boron neutron capture therapy CLL; chronic lymphocytic leukemia; CSCs: cancer stem cells; DLCs: delocalized lipophilic cations; GBM: glioblastoma; ICC: Immunocytochemistry; qPCR: real-time polymerase chain reaction; $\mathrm{IC}_{50}$ : inhibition concentration fifty; TPPs: triphenylphosphonium ions; APL: acute promyelocytic leukemia; HCC: hepatocellular carcinoma. 


\section{INTRODUCTION}

Integral to the demand for the continuous improvement of the balance between benefits, (i.e. preferable tumor cell toxicity) and risks, (i.e. minimization of harmful side effects), the gold standard for modern cancer pharmacology is set by the need to develop chemotherapeutic agents that leave unaffected normal human cells while effectively targeting and destroying malignant tissues with a high degree of selectivity [1]. Cancer cell heterogeneity that contributes to therapy failure is based on molecular and genomic facets which allow a cancer cell to develop peculiar molecular biology and genome function within the context of the surrounding normal cell environment. Although various approaches have been developed thus far aiming to deliver molecularly-targeted innovative anticancer therapeutics and to minimize cancer drug resistance, the main problem of achieving selectivity and specificity for tumor cell cytotoxicity still remains elusive. It has been suggested that as long as technological advancements empower the translational medicine capacity in enabling the pharmacological exploitation of cancer cell molecular and genomic knowledge, the advances to therapeutically overcome heterogeneity and to target the tumor cell microenvironment will occur at increasing rates [2-10]. A major milestone towards organelle-specific drug delivery was reached by the discovery of delocalized lipophilic cations (DLCs) [11]. These molecular structures are guided selectively towards tumors by the higher mitochondrial transmembrane potential $(\sim 60 \mathrm{mV}$ difference) that is consequent to the correspondingly higher metabolic activity of cancer cells relative to that of normal cells [12-16]. The resonance-stabilized delocalization of the positive charge of DLCs, coupled with their inherent lipophilicity, leads to a decrease in the cost associated with the free energy change that accompanies the diffusion of DLCs through cell membranes, and provides the 
driving force for their observed highly selective accumulation (>100 fold) in the mitochondrial matrix of cancer cells $[13,17,18]$ and the associated high ( $>5$ fold) difference between their cytoplasmic and extracellular concentrations [11]. Towards the development of highly selective target-specific anticancer agents that are applicable to boron neutron capture therapy (BNCT) of cancer, this study builds on preliminary evaluations that indicated the selective accumulation of boronated DLC compounds in cancer cells $[19,20]$. In particular, the experimental work focuses on the pharmacological evaluation at cellular and molecular level of four of these boron molecules, the molecular design of which combines the tumor-cell specificity of DLCs with the high boron content of carborane structures [20]. The DLCfunctionalized carboranes exhibit high growth-arrest selectivity towards cancer cell lines (U-87 MG, HSC-3) including primary glioblastoma (GBM) cancer stem cells, in marked contrast to their effect on normal (MRC-5, Vero); importantly, only normal cells are capable of recapitulating their full proliferation potential after exposure to DLC-carboranes in culture. Such cancer cell behavior upon exposure to DLCcarboranes has been shown to happen without induction of apoptosis in the cultures. Moreover, molecular gene expression profiling has indicated that the DLC-carboranes exert their pharmacological properties through the activation of the p53/p21 axis, a crucial molecular pathway long known to control cell cycling and growth arrest. Overall, these results present for the first time evidence that target specific DLCfunctionalized carborane compounds possess an interesting antitumor capacity as standalone cancer therapeutics, in addition to their capacity to act as BNCT agents; potential synergies arising from such combined pharmacological effects render these DLC-carboranes candidate materials for further investigation and clinical evaluation in cancer therapy. 


\section{MATERIALS AND METHODS}

\section{Cell cultures}

The already established permanent cancer model (U-87 MG, HSC-3) along with normal (MRC-5, Vero) cell lines stored and used in a routine manner in our laboratory (Aristotle University of Thessaloniki) were applied throughout this study. Malignant U-87 MG (human epithelial glioblastoma grade IV-astrocytoma) and HSC3 (human oral squamous carcinoma) cells, along with the normal MRC-5 (human fetal lung fibroblasts) and Vero (monkey kidney) cell lines were grown in culture (37 ${ }^{\circ} \mathrm{C}$; humidified atmosphere containing $5 \%$ v/v $\mathrm{CO}_{2}$ ) in DMEM medium supplemented with $10 \%(\mathrm{v} / \mathrm{v}) \mathrm{FBS}, 100 \mu \mathrm{g} / \mathrm{mL}$ of penicillin and $100 \mu \mathrm{g} / \mathrm{mL}$ of streptomycin. To allow the continuous logarithmic phase of cell growth in culture, cell lines were detached before reaching $c a$. $80 \%$ confluency (every 2-3 days) with trypsin-EDTA $(0.25 \% \mathrm{w} / \mathrm{v}$, Life Technologies). The DLC-carborane compounds under consideration (Figure 1) were previously synthesized by our group [20] and dissolved in DMSO and stored at $4{ }^{\circ} \mathrm{C}$. Each cell culture was treated accordingly, as shown below and under figures $(\mathrm{DMSO}$ concentration $\leq 0.2 \% \mathrm{v} / \mathrm{v})$.

\section{Cell propagation in established cell lines and cytotoxicity assessment}

The established malignant (U-87 MG and HSC-3) and normal (MRC-5 and Vero) cell lines were seeded in a 24 -well plate at an initial concentration of $1 \times 10^{5}$ cells $/ \mathrm{mL}$ and allowed to stand for $3 \mathrm{~h}$ before the addition of DLC-carborane compounds at specified concentrations in the range $5 \times 10^{-5} \mathrm{M}$ to $1 \times 10^{-7} \mathrm{M}$. To estimate the $\mathrm{IC}_{50}$ of each compound for each cell line, cells were allowed to grow for additional $48 \mathrm{~h}$ before being harvested by trypsinization and subsequently counted (cell density; number of cells/mL) with the aid of the optical microscope (Neubauer counting champers). Cell 
growth is expressed as a percentage relative to that for the untreated control culture. Cell death was also determined using the trypan blue dye-exclusion method [21].

\section{Cytotoxicity evaluation in primary GBM cancer stem cells $\left(\right.$ CSCs) $\left(\right.$ EGFR $^{\text {neg }}$ and}

\section{EGFR $^{\text {pos }}$ )}

Two primary GBM CSC cultures $\left(\mathrm{EGFR}^{\text {neg }}\right.$ and $\mathrm{EGFR}^{\mathrm{pos}}$ ) that had been isolated and characterized previously by Galli et al., [22] were evaluated after exposure to BOR2, BOR3 or BOR4. For their proper propagation, EGFR ${ }^{\text {neg }}$ cells, which grow in monolayers, and EGFR ${ }^{\text {pos }}$ cells, which grow in neurospheres, were each plated $(25$ $\mathrm{cm}^{2}$ tissue culture flask) at clonal density $\left(2500-5000\right.$ cells $\left./ \mathrm{cm}^{2}\right)$ in Dulbecco's modified Eagle's medium/F-12 medium containing $20 \mathrm{ng} / \mathrm{mL}$ of each EGF and fibroblast growth factor (FGF2; Peprotech, Rocky Hill, NY). The cell proliferation capacity of primary cell lines that had been treated with DLC-carborane compounds $\left(1 \times 10^{-7} \mathrm{M}\right.$ to $\left.1 \times 10^{-4} \mathrm{M}\right)$ was assessed by means of the MTT colorimetric assay, which measures cell viability with reference to the capability of metabolically active cells to reduce the water-soluble yellow MTT into the water-insoluble purple formazan $[23,24] . \mathrm{EGFR}^{\text {neg }}$ or EGFR ${ }^{\text {pos }}$ cells, both at the number of $1.5 \times 10^{4}$ cells, were seeded overnight in $200 \mu \mathrm{L}$ of culture medium using a 96-well plate pre-coated with $50 \mu \mathrm{L}$ MatrigelTM (Becton and Dickinson, San Jose, CA) was removed just before the seeding of cells). Following cell attachment to the plate $(3 \mathrm{~h})$, BOR2, BOR3 and BOR4 were added separately at specified concentrations $\left(1 \times 10^{-7} \mathrm{M}\right.$ to $\left.1 \times 10^{-4} \mathrm{M}\right)$ and the cells were allowed to grow for further $48 \mathrm{~h}$. After this time, $20 \mu \mathrm{L}$ of a $5 \mathrm{mg} / \mathrm{mL}$ solution of MTT that had been warmed and homogenized was added to each well. After $1 \mathrm{~h}$, the insoluble, purple formazan was dissolved by adding $50 \mu \mathrm{L}$ of DMSO. The 96 well-plate was covered with aluminum foil and agitated for $15 \mathrm{~min}$ in a plate 
shaker before quantification by spectrophotometry (plate reader, $570 \mathrm{~nm}$ ). Cell-free wells provided the controls for each compound and medium [24]; results, from at least two independent experiments, are expressed as percentage cell growth relative to that determined for corresponding untreated control cultures.

\section{Immunocytochemistry (ICC) assay}

For the detection of ki-67 proliferation and that of active caspase-3 apoptosis markers, a specified number of EGFR $^{\text {neg }}$ cells $\left(1.5 \times 10^{4}\right.$ cells at final cell culture volume $\left.1 \mathrm{~mL}\right)$ was plated onto Matrigel-coated glass coverslips (12 mm diameter) in a 24 well tissue culture plate $[22,25]$. After $2-3 \mathrm{~h}$, the BOR3 and BOR4 DLC-carboranes were added at their IC50 concentration, which had been determined by means of the MTT assay, and the cells were allowed to further proliferate for 24 or $48 \mathrm{~h}$. The medium was removed and cells were fixed with $300 \mu \mathrm{L}$ of PFA 4\% (20 min; RT) and washed twice with cold PBS 1x. The coverslips were transferred to a new 24-well plate, the cells were permeabilized with $400 \mu \mathrm{L}$ of $0.1 \times$ Triton lysis buffer (10 min) and incubated (2 h, $37{ }^{\circ} \mathrm{C}$ ) with $250 \mu \mathrm{L}$ of primary rabbit anti-caspase-3 (Cell Signaling, Denver, MA) and rabbit anti-ki-67 (Novocastra) antibodies that had been diluted with NGS $10 \%$ (normal goat serum) to a respective final concentration of 1:400 and 1:1000 (v/v). Each well was washed twice with $300 \mu \mathrm{L}$ PBS $1 \times$ and incubated for $45 \mathrm{~min}$ on the orbital shaker with $250 \mu \mathrm{L}$ of the secondary rabbit Alexa $488 \mathrm{~nm}$ (Molecular Probes, Invitrogen) antibody, which had been added at a final concentration of 1:1000 (v/v); plates were covered with aluminum foil. Each well was washed three times with 300 $\mu \mathrm{L}$ PBS $1 \times$ and the nuclei of cells were stained with $300 \mu \mathrm{L}$ of DAPI (Fluka, Buchs, Switzerland) for $10 \mathrm{~min}$ at room temperature. The supernatant was removed, the cells were washed three times with $300 \mu \mathrm{L}$ of PBS $1 \times$ and the cover slips were finally 
transferred onto glass slides, and arranged according to incubation time with the DLC-carborane compounds and the marker of interest. The coverslips were fixed with the glue-like Fluor Save Reagent (Merck, Calbiochem, Darmstadt, Germany) and covered with a micro cover glass. The levels of markers were determined quantitatively under the Nikon Eclipse E600 fluorescence microscope by counting a minimum number of one thousand cells at $330-420 \mathrm{~nm}$ for the DAPI staining and at $450-520 \mathrm{~nm}$ for the ki-67 and active caspase-3. All data presented are the average from triplicate experiments.

\section{Cell pretreatment washout experiments and dilution assays}

Cytotoxicity was assessed further in pretreatment or washout experiments involving human malignant U-87 MG cells (Fig. 3) and normal MRC-5 cells (Fig. 4). Cells were pretreated at the previously determined $\mathrm{IC}_{50}$ concentrations of $\mathrm{BOR} 2, \mathrm{BOR} 3$ and BOR4 for 24,48 or $72 \mathrm{~h}$ (marked in Figure 2 as $-24,-48,-72 \mathrm{hrs}$ ). The replenishment of cells (wash-out time point marked as 0) was achieved by washing out the cells twice with PBS and then with fresh DMEM medium containing no DLC-carborane compounds. Each cell culture was allowed to grow for $120 \mathrm{~h}$; cell density and cell death were monitored every $24 \mathrm{~h}$.

The notable capability of normal MRC-5 cells to regain their full proliferation potential prompted further investigation through dilution assays in which the cell culture was re-suspended and transferred to an expanded cell culture surface with a larger volume of medium. At $72 \mathrm{~h}$, the total volume $(1 \mathrm{~mL})$ of each cell culture was transferred from the 24 well tissue cell culture plate to a $(60 \times 15) \mathrm{mm}$ plate with a total volume of $4 \mathrm{~mL}$ (Figure 4C). After $48 \mathrm{~h}$ had elapsed, the cell culture was diluted further to a final volume of $10 \mathrm{~mL}$ (P10 cell culture dish) and allowed to grow for a 
further $48 \mathrm{~h}$ (time point of $168 \mathrm{~h}$ ). Cell death was determined by means of the Trypan blue staining method [21].

\section{Cytoplasmic RNA isolation and real-time polymerase chain reaction (qPCR)}

RNA isolation from cell cultures that had been treated with DLC-carboranes was carried out by applying an in-house manual protocol based on the phenol-chloroform liquid-liquid extraction of cytoplasmic RNA [21]. The two-step qPCR analysis was performed according to the KAPA SYBR FAST qPCR Kit (KK4602KAPABIOSYSTEMS) manufacturer instructions. Acidic phenol retained RNA preferentially in the upper aqueous phase and minimized RNase activity. After isolation, RNA was tested qualitatively and quantitatively, respectively by a gel electrophoresis assay and by means of the Thermo Scientific NanoDrop 2000 spectrophotometer. Template RNA (200 ng) was used in a cDNA synthesis reaction by following the protocol of the QuantiTect Reverse Transcription Kit (QIAGEN) for cDNA synthesis. A dilution of 1:20 was carried out in order for samples to reach the desirable amplification plots within the range of 25 to $35 \mathrm{Cts}$ (Cycle threshold) for each gene tested. The two-step qPCR analysis was performed according to the KAPA SYBR FAST qPCR Kit (KK4602-KAPABIOSYSTEMS) manufacturer instructions. To ensure the absence of non-desirably amplified products, PCR samples were additionally analyzed by $1 \% \mathrm{w} / \mathrm{v}$ agarose gel electrophoresis, stained with ethidium bromide and photographed under UV light exposure (data not shown). The primer sequences applied in qPCR analysis are presented in Supplemental Table S1.

\section{RESULTS}




\section{DLC-functionalized carboranes exhibit selectivity in their cytotoxicity profile}

and behavior towards cancer cells

DLC-carborane compounds, [BOR2, (o-carboranyl triphenyl phosphonium methylene bromide); BOR3, (nido-carborane salt of tetraphenylphosphonium); BOR4, (nidocarborane salt of dequalinium); and BOR5, (nido-carborane salt of rhodamine B)], with a known propensity to accumulate selectively in cancer cells [20] were selected for pharmacological evaluation along with compound BOR, [1,7-bis(3hydroxypropyl)-meta-carborane], which was used as control (Figure 1). To estimate IC50 values (Table 1), two malignant (U-87 MG and HSC-3) and two normal (Vero and MRC-5) cell lines were separately incubated for $48 \mathrm{~h}$ with each DLC-carborane at a specified concentration in the range $5 \times 10^{-7} \mathrm{M}$ to $1 \times 10^{-4} \mathrm{M}$ (Supplementary Figures S1-S5). Even at high concentrations, BOR exhibited no evidence of cytotoxicity against the malignant and normal cell lines employed for the assessment (Table 1). By contrast, the four DLC-carboranes, exhibited a concentration-dependent cytotoxicity profile with marked differences in potency between malignant and normal cells (Supplementary Figures S1-S5); the most cytotoxic DLC-carborane is BOR4. Reflective of a 5-6 fold difference in potency between malignant and normal cells, the $\mathrm{IC}_{50}$ values of BOR2 were $8.35 \times 10^{-6} \mathrm{M}$ in U-87 MG and $8.18 \times 10^{-6} \mathrm{M}$ in HSC-3 cells, and $2.1 \times 10^{-5} \mathrm{M}$ and $1.45 \times 10^{-5} \mathrm{M}$, respectively in MRC-5 and Vero cells. Indicative of 10-80 fold differences in potency, corresponding values for BOR 3 were $4.5 \times 10^{-6} \mathrm{M}$ (U-87 MG), $2.8 \times 10^{-6} \mathrm{M}$ (HSC-3), $8.1 \times 10^{-5} \mathrm{M}$ (MRC-5) and $>10^{-4} \mathrm{M}$ (Vero). For BOR4, values were determined at $3.2 \times 10^{-6} \mathrm{M}$ (U-87 MG), 3.3 $\times 10^{-6} \mathrm{M}$ (HSC-3), $5 \times 10^{-}$ ${ }^{5} \mathrm{M}$ (MRC-5) and 5.6×10-6 $\mathrm{M}$ (Vero), corresponding to 2 fold differences in potency.

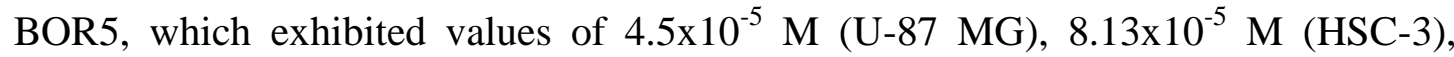
$2.4 \times 10^{-5} \mathrm{M}$ (MRC-5) and $7.15 \times 10^{-5} \mathrm{M}$ (Vero), displayed not substantial differences in 
cell-growth inhibitory potency among the various cultures. Notably, the proportion of dead cells measured in cultures of malignant cells was seen to increase only at the higher concentrations employed $\left(5 \times 10^{-5} \mathrm{M}\right.$ and $\left.1 \times 10^{-4} \mathrm{M}\right)$; this effect was more pronounced in samples that had been treated with BOR2 and BOR4 (data not shown). In view of the observed cancer cell selectivity, an attempt was made to assess the cytotoxicity behavior of the most promising DLC-carboranes, BOR2, BOR3 and BOR4, on CSCs cultures. The $\mathrm{IC}_{50}$ values (Supplementary Figure S6; Table 1) determined in primary GBM EGFR ${ }^{\text {neg }}$ and $\mathrm{EGFR}^{\text {pos }}$ CSCs provide further evidence that the DLC-carborane compounds exhibit a highly selective cytotoxicy profile. BOR3, especially, is characterized by an $\mathrm{IC}_{50}$ value which is about 500 fold lower for CSCs as compared with that for the normal cells.

\section{DLC-carboranes inhibit the proliferation potential of primary GBM CSCs without activating apoptosis}

To assess the cell proliferation potential of primary GBM CSCs that had been treated with DLC-carboranes, the levels of the proliferation marker ki-67 and that of the active caspase- 3 apoptosis marker were examined by means of specific ICC assays. Since only EGFR ${ }^{\text {neg }}$ cultures grow as monolayers, these were selected for testing and incubated with the $\mathrm{IC}_{50}$ concentrations of the most two potent DLC-carboranes, BOR3 and BOR4, for either 24 or $48 \mathrm{~h}$. Figure 2 shows that at both time points under consideration, the levels of the ki-67 proliferation marker were markedly reduced in cell cultures relative to those of the control (untreated) cells. Indeed, the level of ki-67 expression was assessed quantitatively by counting at least 1000 cells. Notably, the ki-67 expression level in treated cultures was seen to be 50-60\% lower after $24-48 \mathrm{~h}$ of treatment (Figure 2G). Since, ki-67 is exclusively expressed in proliferating cells 
and it is detected only during the active cell cycle phases (it is not detectable in the G0 phase) [26], the results confirm the capability of DLC-carboranes to cause growth inhibition in primary GBM CSCs. Since no detectable levels of active caspase-3 have been observed, it is assumed that although these compounds do not induce apoptosis in CSCs, they have a profound inhibitory cell growth potential.

\section{Selective recapitulation of cell proliferation potential consequent to DLC- carborane pretreatment of normal cells}

The pharmacological screening observation that the DLC-carboranes under consideration induced limited cell death at concentrations close to their $\mathrm{IC}_{50}$ values, prompted pretreatment washout experiments. To this end, the cell cultures were each treated continuously at the $\mathrm{IC}_{50}$ concentrations of $\mathrm{BOR} 2, \mathrm{BOR} 3, \mathrm{BOR} 4$ and $\mathrm{BOR} 5$ for 24,48 or $72 \mathrm{~h}$, and subsequently, at the time point referred as " 0 ", a washout step was introduced by allowing cells to grow in agents-free medium. To facilitate the determination of the logarithmic and plateau phases of cell growth, an untreated control culture was allowed to grow in parallel to the same sequence of treatments. A typical pretreatment washout experiment mirroring the behavior of U-87 MG and MRC-5 cells pretreated with BOR2 is presented in Figure 3 and 4, respectively. The proliferation of U-87 MG cells is irreversibly inhibited, even after the washout step (Figure 3A), and the level of cell death seen in culture is very low (Figure 3B).This effect is independent of the timescale of the pretreatment period $(24,48$ or $72 \mathrm{~h})$. The observation that untreated control U-87 MG cells exhibit only $20 \%$ cell death after $120 \mathrm{~h}$, when maximum confluency and nutrient starvation exists in culture, suggests that these cells enter cell cycle arrest. Normal MRC-5 cells are characterized by a different profile: the initial inhibition of cell growth, consequent to exposure to DLC- 
carboranes at IC50, is followed, soon after transfer to BOR2-free medium by a proliferation phase, which is in turn followed by a plateau phase (Figure 4A). Such behavior unveils the capability of MRC-5 cells to recapitulate their potential to proliferate even after exposure to BOR2. Indicative of an inherent capability to regain its full proliferation potential, the MRC-5 cell culture that had been pretreated for $24 \mathrm{~h}$ before being moved to BOR2-free medium achieved similar cell density to that of the untreated control culture. The proportion of cell death in cultures exposed to prolonged treatments is markedly higher, but this may be explained, at least in part, by issues of confluency and nutrient starvation that arise consequent to the very considerable increase in cell numbers (Figure 4B,D). Notable is the behavior of U-87 MG and MRC-5 cells at the plateau phase of their growth in culture (Figure 3B and 4B); the response of normal MRC-5 is in marked contrast to that of malignant U-87 MG cells, which are unable to overcome the cytotoxicity effect triggered by the BOR2 pretreatment. To assess the capability of normal MRC-5 cells to regain their proliferative potential further, an experiment was designed involving the serial medium dilution of cells for the purpose of ensuring the continuous logarithmic growth of cell cultures. The data obtained revealed (Figure 4C) that the cell proliferation capability of pretreated MRC-5 cells occurs in a time-dependent manner. All pretreated cell cultures were characterized by a marked increase in cell proliferation in the time period between 72 and $168 \mathrm{~h}$. The increase observed for the $72 \mathrm{~h}$ BOR2-pretreated cell culture was ca. $70 \%$ while that at 24 and $48 \mathrm{~h}$ was ca. 95\%. The proportion of cell death in the logarithmic-phase serially diluted cultures was markedly lower than that of those grown continuously in the original plate from the initial cell cultures (cf. Figure 4D and 4B). Since similar behavior was observed in experiments involving the assessment of BOR3 and BOR4 against U-87 MG and 
MRC-5 cells (Supplementary Figures S7 and S8) it is assumed that these effects are integrally related to chemical structural features of the carborane compounds under evaluation. To confirm the capability of normal cells to regain their proliferative potential, another cell line was tested against the most cytotoxic DLC-carborane (BOR4), namely: normal monkey Vero cells. Again, the results revealed the capability of BOR4-pretreated Vero cells to regain their proliferation capacity following transfer and culturing in BOR4-free medium (data not shown).

The cancer-cell-specific cytotoxicity behavior of DLC-carboranes is mediated by activation of the $\mathrm{p53/p21}$ signaling pathway

The evaluations of cell kinetics from the continuous and pretreatment washout treatments with DLC-carboranes prompted an attempt to elucidate the underlying molecular mechanisms that contribute to the observed cellular responses through the qPCR analysis of the expression level of cell cycle and apoptosis related genes. To this end, the malignant U-87 MG and normal MRC-5 cells were each treated continuously for 24 or $72 \mathrm{~h}$ with the $\mathrm{IC}_{50}$ concentrations of BOR2, BOR3 and/or BOR4 (Table 1). The assessment was focused on 14 genes (including the housekeeping $\beta$-actin; Supplementary Table S1; Figure 5 and 7). Considering the pronounced changes in the gene expression profiles upon continuous treatment of cells with DLC-carboranes, a complementary set of growth kinetics experiments was performed in order to investigate the effects of pretreatment washout experiments at the molecular level. The analysis of cultures that had been pretreated with DLCcarboranes $(48 \mathrm{~h})$ was carried out at 48 and at $72 \mathrm{~h}$ following the growth of cells in media that were free from DLC-carboranes (Figure 6 and 8). U-87 MG cells exhibits a similar, time-dependent profile irrespective of the DLC-carborane used (BOR2, 
BOR3 and/or BOR4) for their continuous treatment (Figure 5A-C). Cells treated with the $\mathrm{IC}_{50}$ concentration of $\mathrm{BOR} 2$ exhibit an increase in the level of expression of apoptotic caspase- 8 , caspase- 3 and bax genes, and also an increase in the expression of the bcl-2 anti-apoptotic gene. The marked increase in the levels of p53 and p21 mRNA (Figure 5A) indicates the activation of the p53/p21 signaling pathway. The continuous treatment of $\mathrm{U}-87 \mathrm{MG}$ cells at the $\mathrm{IC}_{50}$ concentration of BOR3 indicates a gene expression profile that is similar apart from the notable exception in the expression of caspase- 8 (Figure 5B). The continuous treatment of U-87 MG cells with the $\mathrm{IC}_{50}$ concentration of BOR4 also induces an augmentation in the level of expression of apoptotic caspase- 8 , bad and bax genes, a parallel increase in the expression of the anti-apoptotic bcl-2 gene and an extensive increase of the expression of the p53/p21 gene axis (Figure 5C). Especially for BOR4 which is the more potent compound in cell-growth inhibitory capacity, by repeating such analysis in U-87 MG cells but at much lower than $\mathrm{IC}_{50}$ concentration $\left(1 \times 10^{-6} \mathrm{M}\right)$ of $\mathrm{BOR} 4$ was shown a concentration-dependent effect on these gene expression changes (data not shown). Notably, during the pretreatment washout experiment (Figure 6A-C) the molecular analysis of U-87 MG cells that had been pretreated with BOR2 or BOR3 revealed a similar pattern of gene expression: the gene expression levels of c-myc, cyclin D1, Cdk4, p53 and p21 increased, whereas those of bcl-2 and bax decreased. The analysis of BOR4-pretreated U-87 MG cells indicated highly augmented levels of gene expression in the pro-apoptotic bad gene and also in the p53/p21 gene axis. On contrary, the gene expression profiling of MRC-5 cells that had been exposed to continuous treatment with DLC-carboranes (BOR2, BOR3 and/or BOR4) at their $\mathrm{IC}_{50}$ concentration does not reveal any major effects (Figure 7A-C). From the panel of 14 genes analyzed, in MRC-5 cells only five cell cycle and apoptosis related genes were 
seen to be amplified by qPCR, namely: Cdk2, Cdk6, bad, bax and bcl-2. Consistent with literature reports [27-31] the gene expression levels of p53, p21, caspase-3-8-9, cyclin D1, Cdk4 and c-myc were repeatedly undetectable in untreated (control) MRC5 cells. In accordance with their cell kinetics profile of MRC-5 cells in culture, no significant differences were observed in the levels of gene expression during the pretreatment washout experiments (Figure 8) as compared with the untreated control cultures. For purposes of comparison with changes seen in normal MRC-5 cells, a similar molecular analysis protocol was adopted in a study involving normal Vero cells that had been treated with the IC50 concentration of BOR4, either continuously or upon pretreatment wash out methodology (data not shown). Consistent with the observed differences in the effects induced by DLC-carboranes to the gene expression profiles of normal and malignant cells, the profile of treated Vero cells was seen to coincide with that of MRC-5 cells, and consequently to be markedly different to that yielded by the similar treatment of malignant U-87 MG cells.

\section{DISCUSSION}

It is widely understood that cancer is a heterogeneous disease in which tumor cell heterogeneity contributes to therapy failure and disease recurrence [5]. In this study, cellular and molecular pharmacological data demonstrate that DLC-carborane compounds target cancer and primary GBM CSCs highly selectively and also that these agents exert a very significant pharmacological behavior while sparing normal cells. Based on the principle of the elimination of CSCs toward achieving patient long-term cure rates in the clinical setting $[3,6,7]$, it is of significance that DLCcarborane compounds exert such remarkable effect on GBM CSC lines. The effect is most meaningfully demonstrated by the determined $\mathrm{IC}_{50}$ values, which are markedly 
lower than those calculated for normal cells ( $c a$. 10-500 fold difference in potency), and further supported by pretreatment and dilution assays. Moreover, the observation that the tested DLC-functionalized carboranes exhibit selective cytotoxicity towards primary GBM CSCs indicates their potential to drive cytotoxic actions to heterogeneous tumor cell subpopulations. This is an issue of some significance since such genetically- and molecularly-diverse cell types crucially restricts the therapeutics outcome and correlates with the emergence of cancer drug resistance [8]. Notably, following their pretreatment with DLC-carboranes, only normal cells were seen to recapitulate their full proliferation potential in media that were free from these compounds; this effect was verified through dilution assays. The selective effect of the functionized carboranes appears to be linked to their DLC moiety, which elicits a cytotoxic response with a therapeutic potential through mitochondrial targets $[11,18]$, since: a) triphenylphosphonium ions (TPPs), have been exploited as small molecule directing groups to achieve mitochondrial delivery [17]; b) rhodamine functionalities have been utilized in mitochondria-specific dyes [11,15,20]; and, c) dequalinium (DQA) has been evaluated in a therapeutic approach for the treatment of B-cell chronic lymphocytic leukemia (B-CLL), acute promyelocytic leukemia (APL) and hepatocellular carcinoma (HCC) [32,33].

To gain insight on the molecular mechanisms underlying the pharmacological profile of DLC-functionalized carboranes, the treatment of both malignant and normal cells was conducted at the experimentally calculated $\mathrm{IC}_{50}$ values for each cell type, while higher concentrations are applied for normal cell cultures. Even under this treatment regime, however, a marked gene expression augmentation of the p53/p21 axis was seen to occur in malignant cells only (U-87 MG). The increased levels of p53 and p21 gene expression, especially in the case of BOR4-treated U-87 MG cells, suggests that 
the stimulus that malignant cells receive during their treatment with DLC-carboranes activates the tumor suppressor protein p53, which mediates the DNA damage-induced checkpoint mechanism through the trans-activation of growth inhibitory genes, such as p21. This in turn leads malignant cells to p53-dependent G1 growth arrest [34-38]. It is known that cellular progression halts until genetic errors are fixed or the cellular environment becomes permissive to the proper DNA synthesis and cell cycle progression [38-40], but this however, was not observed on treatment with DLCcarboranes, since qPCR analysis revealed the gene expression profile of malignant cells had not been reversed after the removal of agents from the culture. In the case of BOR4, an even more augmented level of p53/p21 gene expression was noticed after its removal, despite the parallel increase in the expression level of cell cycle driving genes, like c-myc, cyclin D1 and cdk4. This observation suggests that malignant cells were unsuccessful in their attempt to overcome their p53/p21-mediated proliferation blockade by transcriptionally activating specific cycle-related gene cascade mechanisms [41]. These findings suggest the continuing effect of DLC-functionalized carboranes, like BOR4, on malignant cells after their removal from the culture. The permanency of cytotoxic damage to tumor cells is indicated by the differences in gene expression levels observed in parallel experiments involving normal cells. Alternatively, the unmatched gene expression profiles seen in glioblastoma U87 MG and normal MRC-5 cell cultures exposed to carboranes along with their sensitivity to respond to proliferation (high range in $\mathrm{IC}_{50}$ values) and cell-cycle behavior in pretreatment/washout experiments (ability only for normal cells to recapitulate growth rates), imply that the underlying molecular mechanisms trigger different responses to crucial cellular decisions. For example, p53 induces tissue-specific apoptosis through alternative mechanisms mediated by transcription-dependent (e.g. trans-activation of 
bax or trans-repression of bcl-2) or transcription-independent (mitochondria-targeted repression of bcl-2 and bcl-XL) pathways [42, 43]. To this end, the p53-mediated growth inhibitory signaling has been shown to be affected by the mutational status of p53 gene in various cells types, a fact leading to modified transcriptional capacity to target gene activation as well as to cell cycle regulatory gene suppression [44]. The molecular profiling analysis has shown that only exposure of U87 MG cells to carboranes (BOR2, BOR3, BOR4) resulted in transcriptional activation of genes related to cell-cycle arrest (e.g. p53/p21 axis), to apoptosis (bax, bad, caspases 3 and 9), to survival (e.g. bcl-2), as well as to mitogenesis (e.g. c-myc, cyclin D1, cdk4). Noteworthy, in carborane-treated cells the expression of both pro-apoptotic (bax, bad) and pro-survival genes (bcl-2) of bcl-2 family members have been activated. Although the observed pattern of gene expression implies signaling pathways with opposing cellular response functions, however, it has resulted in profound growtharrest in culture without the activation of apoptosis mechanisms. Moreover, upon the pretreatment experiments, (where after their initial exposure to carboranes, U87 MG cells are grown to agents-free medium), it has been noticed that also the expression of mitogenic-related genes (c-myc, cyclin D1 and cdk4) is increased, in parallel with the transcriptional activation of p53/p21axis that was also seen in these cultures. The latter, is an interesting observation that can be explained as an unsuccessful attempt of cells after the removal of carboranes form the culture to overcome the agent-triggered cell-cycle arrest mediated by p53/p21. Importantly enough, through these opposing molecular pathways impinging on to either proliferation and survival, or growth arrest and apoptosis [45-47], the treatment of glioblastoma U87 MG cultures with carboranes leads to a such functional balance in gene expression that permanently leads them to inability for cell cycling and division. Overall, these bifunctional acting 
carborane compounds represent a new class of anticancer agents whose pharmacological efficacy and safety profiles deserve further clinical investigation and verification. Accordingly, the pharmacological evaluation of the DLC-carboranes indicates not only their potential value to BNCT as previously shown, [20] but also implies their remarkable therapeutic potential as stand-alone anticancer drugs.

\section{ACKNOWLEDGMENT}

This work was partially funded by interdepartmental public funds of Aristotle University Research Committee to ISV. EDT is recipient of a STSM fellowship from the COST 1106 action to work at Rosella Galli’s lab (San Raffaele Scientific Institute, Milan). We would like to thank Dr. Rosella Galli, (Group Leader at Neural Stem Cell Biology Unit, Division of Regenerative Medicine, Stem Cells and Gene Therapy, San Raffaele Scientific Institute, Milan), for her kind offer of EGFR ${ }^{\text {neg }}$ and $\mathrm{EGFR}^{\text {pos }}$ primary GBM CSCs and also for allowing us to perform that experiments in her laboratory. Also, we thank Dr. Narayanan Ashwin (Postdoctoral fellow at Rosella Galli's lab) for his help in the EGFR ${ }^{\text {neg }}$ and EGFR $^{\text {pos }}$ handling and the immunofluorescence microscopy.

\section{CONFLICT OF INTEREST AND FUNDING}

The authors disclose no conflict of interest. This work was partially funded by interdepartmental public funds of Aristotle University Research Committee to ISV and STSM fellowship from the CMST COST Action CM1106 to EDT.

\section{REFERENCES}


1. Atkins JH, Gershell LJ. Selective anticancer drugs. Nat Rev Drug Discov. 2002; $1: 491-492$.

2. Hanahan D, Weinberg RA. Hallmarks of cancer: the next generation. Cell $2011 ; 144: 646-674$

3. Borst P. Cancer drug pan-resistance: pumps, cancer stem cells, quiescence, epithelial to mesenchymal transition, blocked cell death pathways, persisters or what? Open Biol. 2012; $2: 120066$.

4. Vizirianakis IS, Fatouros DG. Personalized nanomedicine: paving the way to the practical clinical utility of genomics and nanotechnology advancements. Adv Drug Deliv Rev. 2012; 64: 1359-1362.

5. Kreso A, Dick JE. Evolution of the cancer stem cell model. Cell Stem Cell. $2014 ; 14: 275-291$.

6. Ismail F, Winkler DA. Getting to the source: selective drug targeting of cancer stem cells. ChemMedChem. 2014; 9: 885-898.

7. Würth R, Barbieri F, Florio T. New molecules and old drugs as emerging approaches to selectively target human glioblastoma cancer stem cells. Biomed Res Int. 2014; 2014, 126586.

8. Gottesman MM, Lavi O, Hall MD, Gillet JP, Towards a Better Understanding of the Complexity of Cancer Drug Resistance. Annu Rev Pharmacol Toxicol. 2015, DOI: 10.1146/annurev-pharmtox-010715-103111.

9. Tong R, Kohane DS. New Strategies in Cancer Nanomedicine. Annu Rev Pharmacol Toxicol. 2015, DOI: 10.1146/annurev-pharmtox-010715-103456.

10. Vizirianakis, IS, Mystridis GA, Avgoustakis K, Fatouros DG, Spanakis M. Enabling personalized cancer medicine decisions: The challenging 
pharmacological approach of PBPK models for nanomedicine and pharmacogenomics. Oncol Rep. 2016, In Press.

11. Madak JT, Neamati N. Membrane permeable lipophilic cations as mitochondrial directing groups. Curr Top Med Chem. 2015; 15: 745-766.

12. Modica-Napolitano JS, Aprille JR. Basis for the selective cytotoxicity of rhodamine 123. Cancer Res. 1987; $47: 4361-4365$.

13. Modica-Napolitano JS, Aprille JR. Delocalized lipophilic cations selectively target the mitochondria of carcinoma cells. Adv Drug Deliv Rev. 2001; 49: 63-70.

14. Fulda S, Galluzzi L, Kroemer G. Targeting mitochondria for cancer therapy. Nat Rev Drug Discov. 2010; 9 : 447-464.

15. Wen S, Zhu D, Huang P. Targeting cancer cell mitochondria as a therapeutic approach. Future Med Chem. 2013; 5 : 53-67.

16. Modica-Napolitano J S, Weissig, V. Treatment strategies that enhance the efficacy and selectivity of mitochondria-targeted anticancer agents. Int J Mol Sci. $2015 ; 16: 17394-17421$.

17. Pathania D, Millard M, Neamati N. Opportunities in discovery and delivery of anticancer drugs targeting mitochondria and cancer cell metabolism. Adv Drug Deliv Rev. 2009; 61: 1250-1275.

18. Kurtoglu M, Lampidis TJ. From delocalized lipophilic cations to hypoxia: blocking tumor cell mitochondrial function leads to therapeutic gain with glycolytic inhibitors. Mol Nutr Food Res. 2009; 53 : 68-75

19. Barth RF, Coderre JA, Vicente MG, Blue TE. Boron neutron capture therapy of cancer: Current status and future prospects. Clin Cancer Res. 2005; 11: $3987-4002$ 
20. Calabrese G, Gomes ACNM, Barbu E, Nevell TG, Tsibouklis J. Carboranebased derivatives of delocalised lipophilic cations for boron neutron capture therapy: synthesis and preliminary in vitro evaluation. J Mater Chem. 2008; 18 : 4864-4871.

21. Vizirianakis IS, Tsiftsoglou AS. Blockade of murine erythroleukemia cell differentiation by hypomethylating agents causes accumulation of discrete small poly(A)- RNAs hybridized to 3'-end flanking sequences of beta(major) globin gene. Biochim Biophys Acta 2005; 1743: 101-114.

22. Galli R, Binda E, Orfanelli U, Cipelletti B, Gritti A, De Vitis S, et al. Isolation and characterization of tumorigenic, stem-like neural precursors from human glioblastoma. Cancer Res. 2004; 4: 7011-7021.

23. Galli R. The neurosphere assay applied to neural stem cells and cancer stem cells. Methods Mol Biol. 2013; 986: 267-277.

24. Theodoropoulos D, Rova A, Smith JR, Barbu E, Calabrese G, Vizirianakis IS, et al. Towards boron neutron capture therapy: the formulation and preliminary in vitro evaluation of liposomal vehicles for the therapeutic delivery of the dequalinium salt of bis-nido-carborane. Bioorg Med Chem Lett. 2013; 23: 6161-6166.

25. Engels C C, Ruberta F, de Kruijf E M, van Pelt GW, Smit VT, Liefers GJ, et al. The prognostic value of apoptotic and proliferative markers in breast cancer. Breast Cancer Res Treat. 2013; 142: 323-339.

26. Bullwinkel J, Baron-Lühr B, Lüdemann A, Wohlenberg C, Gerdes J, Scholzen T. Ki-67 protein is associated with ribosomal RNA transcription in quiescent and proliferating cells. J Cell Physiol 2006; 206: 624-635. 
27. Irving J, Feng J, Wistrom C, Ikaart M, Villeponteau B. An altered repertoire of fos/jun (AP-1) of replicative senescent. Exp Cell Res. 1992; 202: 161-166.

28. Alcorta DA, Xiong Y,Phelps D, Hannon G, Beach D, Barrett JC. Involvement of the cyclin-dependent kinase inhibitor p16 (INK4a) in replicative senescence of normal human fibroblasts. Proc Natl Acad Sci U.S.A. 1996; 93: 1374213747.

29. Chen J-H, TsengT-H, Ho Y-C, Lin H-H, Lin W-L, Wang C-J. Gaseous nitrogen oxides stimulate cell cycle progression by rubidium phosphorylation via activation of cyclins/cdks. Toxicol Sci. 2003; 76: 83-90.

30. Zhang K, Lu J, Mori T, Smith-Powell L, Synold TW, Chen S, et al. Baicalin increases VEGF expression and angiogenesis by activating the ERRa/PGC-1a pathway. Cardiovascular Res. 2011; 89: 426-435.

31. Binet R, Ythier D, Robles AI, Collado M, Larrieu D, Fonti C, et al. WNT16B is a new marker of cellular senescence that regulates p53 activity and the phosphoinositide 3-kinase/AKT pathway. Cancer Res. 2009; 69: 9183-9191.

32. Ribeiro B, Ferreira L, Gonçalves C, Neves S, Araújo M, Carvalho F, et al. Delocalized lipophilic cations as a new therapeutic approach in cancer. BMC Proc. 2010;4(Suppl. 2) : P30.

33. García-Pérez AI, Galeano E, Nieto E, Estañ MC, Sancho P. Dequalinium induces cytotoxicity in human leukemia NB4 cells by downregulation of Raf/MEK/ERK and PI3K/Akt signaling pathways and potentiation of specific inhibitors of these pathways. Leuk Res. 2014; 38 : 795-803.

34. Agarwal ML., Agarwal A, Taylor WR, Stark GR. P53 controls both the G2/M and the G1 cell cycle checkpoints and mediates reversible growth arrest in human fibroblasts. Proc Natl Acad Sci U.S.A. 1995; 92: 8493-8497. 
35. Waldman T, Kinzler KW, Vogelstein B. p21 is necessary for the p53-mediated G1 arrest in human cancer cells. Cancer Res. 1995; 55: 5187-5190.

36. Macleod KF, Sherry N, Hannon G, Beach D, Tokino T, Kinzler K, et al. p53Dependent and independent expression of p21 during cell growth, differentiation and DNA damage. Genes Dev. 1995; 9: 935-944.

37. Israels ED, Israels LG. The cell cycle. The Oncologist 2000; 5: 510-513.

38. He G, Siddik ZH, Huang Z, Wang R, Koomen J, Kobayashi R et al. Induction of p21 by p53 following DNA damage inhibits both Cdk4 and Cdk2 activities. Oncogene 2005; 24: 2929-2943.

39. Haupt S, Berger M, Goldberg Z, Haupt Y. Apoptosis: The p53 network. J Cell Sci. 2003; 116: 4077-4085.

40. Abbas T, Dutta A. p21 in cancer: intricate networks and multiple activities. Nat Rev Cancer 2009; 9: 400-414.

41. Gartel A L, Shchors K. Mechanisms of c-myc-mediated transcriptional repression of growth arrest genes. Exp Cell Res. 2003; 283: 7-21.

42. Slee EA, O'Connor DJ, Lu X. To die or not to die: how does p53 decide? Oncogene 2004; 23: 2809-2818.

43. Fridman JS, Lowe SW. Control of apoptosis by p53. Oncogene 2003; 22: 9030-9040.

44. Parikh N, Hilsenbeck S, Creighton CJ, Dayaram T, Shuck R, Shinbrot E, Xi L, Gibbs RA, Wheeler DA, Donehower LA. Effects of TP53 mutational status on gene expression patterns across 10 human cancer types. J Pathol 2014; 232: $522-533$.

45. Marcel V, Catez F, Diaz J-J. p53, a translational regulator: contribution to its tumour-suppressor activity. Oncogene 2015; 34: 5513-5523. 
46. Sochalska M, Tuzlak S, Egle A, Villunger A. Lessons from gain- and loss-offunction models of pro-survival Bcl2 family proteins: implications for targeted therapy. FEBS J 2015; 282: 834-849.

47. Delbridge AR, Strasser A. The BCL-2 protein family, BH3-mimetics and cancer therapy. Cell Death Differ. 2015; 22: 1071-1080. 
Table 1. $\mathrm{IC}_{50}$ values of the bifunctional carborane compounds tested in various normal, cancer and primary GBM CSCs.

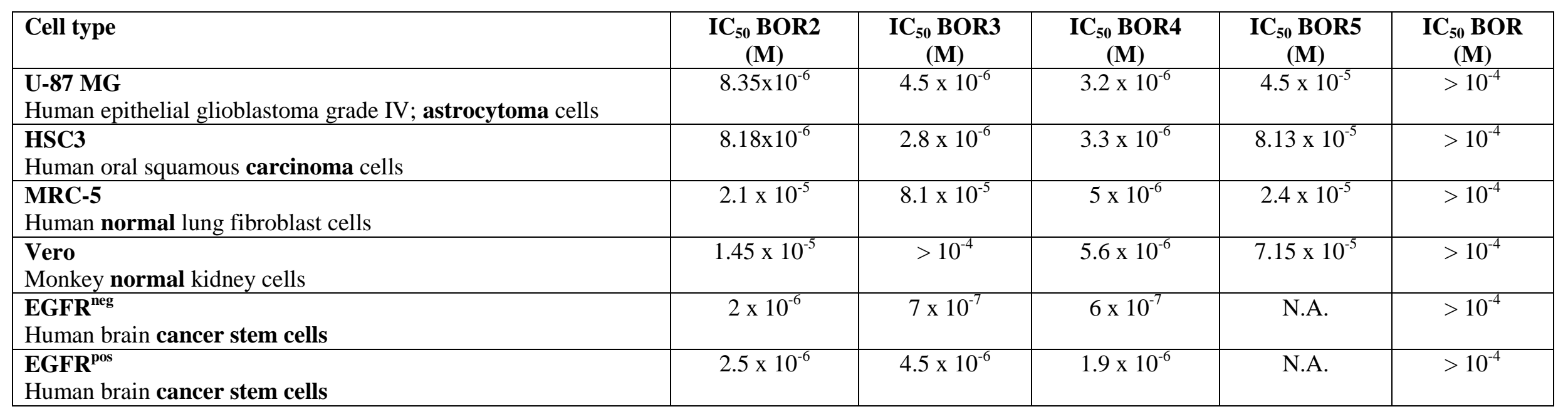

N.A.: Not analyzed. 


\section{LEGENDS TO FIGURES}

Figure 1: Chemical structures of delocalized lipophilic cation-functionalized carboranes.

The structure of tested compounds: BOR (1,7-bis(3-hydroxypropyl)-meta-carborane), BOR2 (o-carboranyl triphenyl phosphonium methylene bromide), BOR3 (nidocarborane salt of tetraphenylphosphonium), BOR4 (nido-carborane salt of dequalinium) and BOR5 (nido-carborane salt of rhodamine B).

Figure 2: Assessment of levels of the ki-67 proliferation marker in primary GBM CSCs grown in the presence of DLC-carboranes. EGFR ${ }^{\text {neg }}$ primary GBM CSCs were each treated for $24 \mathrm{~h}$ (at left) and/or $48 \mathrm{~h}$ (at right) with the $\mathrm{IC}_{50}$ concentrations of BOR3 $\left(7 \times 10^{-7} \mathrm{M}\right)$ and BOR4 $\left(6 \times 10^{-7} \mathrm{M}\right)$, Table 1, before the measurement of ki-67 levels (see "Materials and Methods"). Panels A and B, untreated (control) cultures; Panels C and D, BOR3-treated cultures; Panels E and F, BOR4-treated cultures; Panels A, C and E, DAPI-stained cell nuclei; Panels B, D and F, ki-67 expression levels; Panel G, quantification of ki-67 by means of the data obtained from panels B, D and F. The results are presented as a percentage of the ki-67 expression determined for untreated control cultures and represent the mean $( \pm$ SD) of two independent experiments. Statistical analysis was performed by paired t-test. A significance level of $p<0.05$ denoted significance.

Figure 3: Assessment of cell proliferation potential of U-87 MG cells in culture following their pretreatment with BOR2 for specified time intervals. Malignant human U-87 MG cells that had been grown in culture were treated with the $\mathrm{IC}_{50}$ concentration of BOR2 $\left(8.35 \times 10^{-6} \mathrm{M}\right)$ for specified time intervals (-24, $-48-72 \mathrm{~h}$; pretreatment). After this time, cells were washed out (time 0) and allowed to grow in culture in BOR2-free medium. Cell growth (Panel A) and cell death (Panel B) were assessed as described under "Materials and Methods". The pretreatment of U-87 MG cells with BOR2 inhibited the cells capacity to proliferate, even when cells were grown in agents-free 
media. The data shown above indicate a representative experiment where three independent measurements were used to calculate the mean $( \pm \mathrm{SD})$. A biological replication of this experiment was carried out twice with similar results. Statistics was performed by paired t-test. A significance level of $\mathrm{p}<0.05$ denoted significance.

Figure 4: Assessment of cell proliferation potential of MRC-5 cells in culture following their pretreatment with BOR2 for specified time intervals. Normal human MRC-5 cells that had been grown in culture were treated with the $\mathrm{IC}_{50}$ concentration of BOR2 $\left(2.1 \times 10^{-5} \mathrm{M}\right)$ for specified time intervals (-24, $-48-72 \mathrm{~h}$; pretreatment). After this time, cells were washed out (time 0) and allowed to grow in culture in BOR2-free medium. Cell growth (Panel A) and cell death (Panel B) were assessed as described under "Experimental section”. In BOR2-free media, BOR2-pretreated MRC-5 cells recapitulated their full proliferation potential, even reaching the plateau phase of growth at which cell death occurs due to confluency (Panel B). To establish the conditions under which cells exhibit unrestricted proliferation capacity, BOR2-pretreated MRC-5 cells were subjected to proper dilution assays (see at "Materials and Methods"). Panel C: Time-dependent kinetics of cell growth; the first arrow pinpoints cell cultures that had been transferred from the 24 -well plate $(1 \mathrm{~mL}$ volume $)$ to the $(60 \times 15) \mathrm{mm}$ plate $(4 \mathrm{~mL}$ volume); the second arrow is directed to cells that had been transferred from the (60 $\mathrm{x}$ 15) $\mathrm{mm}$ plate (4 mL volume) to P10 culture dish (10 mL volume). Since cells do not reach a plateau phase of growth, cell death is minimal (Panel D). The data shown above indicate a representative experiment where three independent measurements were used to calculate the mean $( \pm S D)$. A biological replication of this experiment was carried out twice with similar results. Statistics was performed by paired t-test. A significance level of $\mathrm{p}<0.05$ denoted significance.

Figure 5: qPCR analysis of U-87 MG cells exposed to DLC-carboranes. The gene expression profiles for proliferation- and/or apoptosis-related molecules in malignant U- 
$87 \mathrm{MG}$ cells that had been treated with the $\mathrm{IC}_{50}$ concentrations of BOR2 (Panel A), BOR3 (Panel B) or BOR4 (Panel C) for $24 \mathrm{~h}$ or $72 \mathrm{~h}$ is presented. The analysis was carried out with qPCR with the primers shown in Supplementary Table S1, as described under "Materials and Methods". The data shown above indicate a representative experiment where three independent measurements were used to calculate the mean $( \pm$ SD). A biological replication of this experiment was carried out at least twice with similar results. Statistics was performed by paired t-test. A significance level of $p<0.05$ denoted significance.

Figure 6: qPCR analysis of U-87 MG cells pretreated with DLC-carboranes and then allowed to grow under agents-free conditions. Gene expression molecular analysis of malignant U-87 MG cells that had been pretreated for $48 \mathrm{~h}$ with BOR2 (Panel A), BOR3 (Panel B) or BOR4 (Panel C), washed out and allowed to grow under agent-free conditions for an additional 48 or $72 \mathrm{~h}$. The analysis was performed as shown under Figure 5. The data shown above indicate a representative experiment where three independent measurements were used to calculate the mean $( \pm \mathrm{SD})$. A biological replication of this experiment was carried out at least twice with similar results. Statistics was performed by paired t-test. A significance level of $\mathrm{p}<0.05$ denoted significance.

Figure 7: qPCR analysis of MRC-5 cells exposed to DLC-carboranes. Similarly to the analysis shown under Figure 5, the gene expression profiles for proliferation- and apoptosis-related molecules in normal human MRC-5 cells that had been treated with the $\mathrm{IC}_{50}$ concentrations of BOR2 (Panel A), BOR3 (Panel B) or BOR4 (Panel C) for $24 \mathrm{~h}$ or $72 \mathrm{~h}$ is presented. The data shown above indicate a representative experiment where three independent measurements were used to calculate the mean $( \pm \mathrm{SD})$. A biological replication of this experiment was carried out at least twice with similar results. Statistics was performed by paired t-test. A significance level of $\mathrm{p}<0.05$ denoted significance. 
Figure 8: qPCR analysis of MRC-5 cells pretreated with DLC-carboranes and then allowed to grow under agents-free conditions. Similarly to the analysis shown under Figure 6, the gene expression molecular analysis of MRC-5 cells that had been pretreated for $48 \mathrm{~h}$ with BOR2 (Panel A), BOR3 (Panel B) or BOR4 (Panel C), washed out and allowed to grow under agent-free conditions for an additional 48 or $72 \mathrm{~h}$. The data shown above indicate a representative experiment where three independent measurements were used to calculate the mean $( \pm \mathrm{SD})$. A biological replication of this experiment was carried out at least twice with similar results. Statistics was performed by paired t-test. A significance level of $\mathrm{p}<0.05$ denoted significance. 

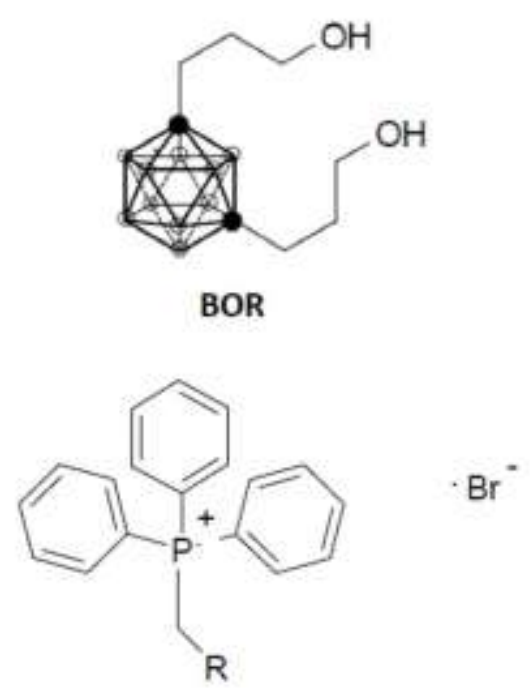

$\mathrm{R}=$ o-carbonyl

BOR2<smiles>c1ccc([P+](c2ccccc2)(c2ccccc2)c2ccccc2)cc1</smiles>

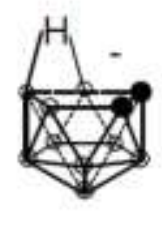

BOR3

Figure 1

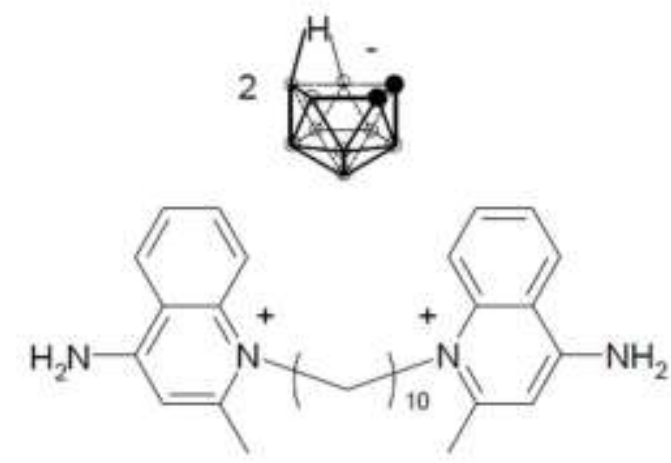

BOR4

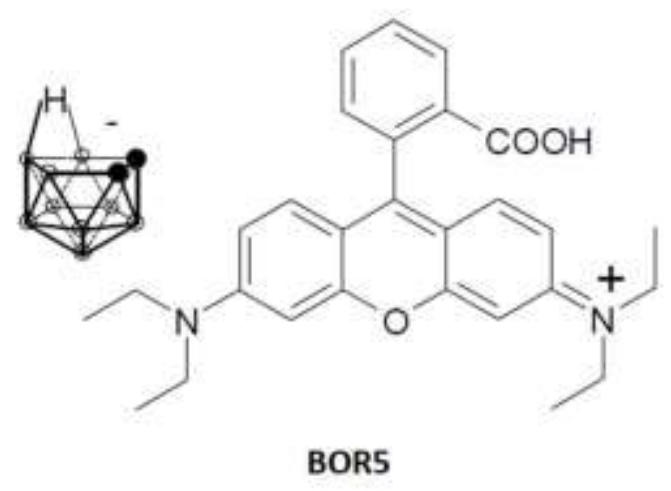



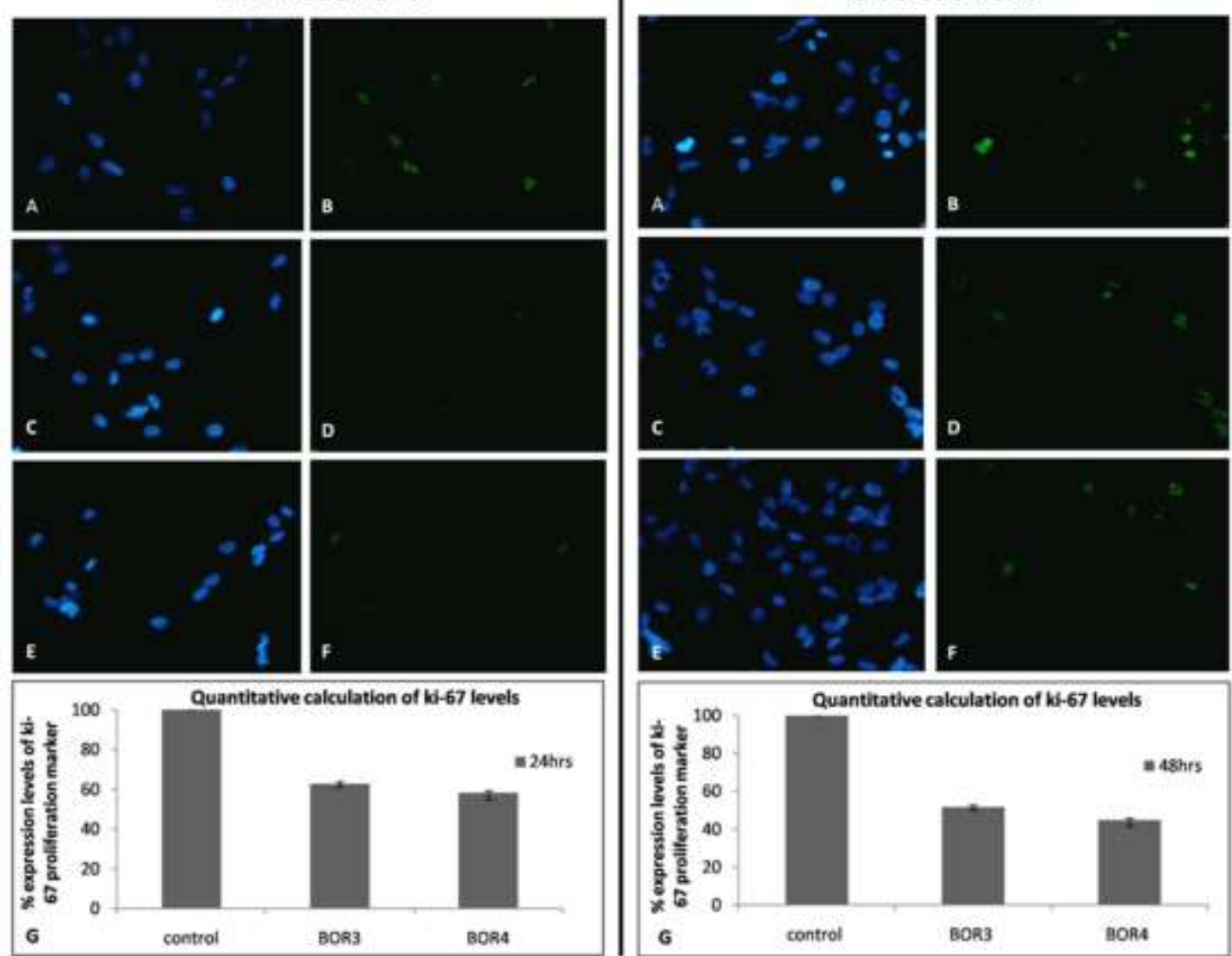

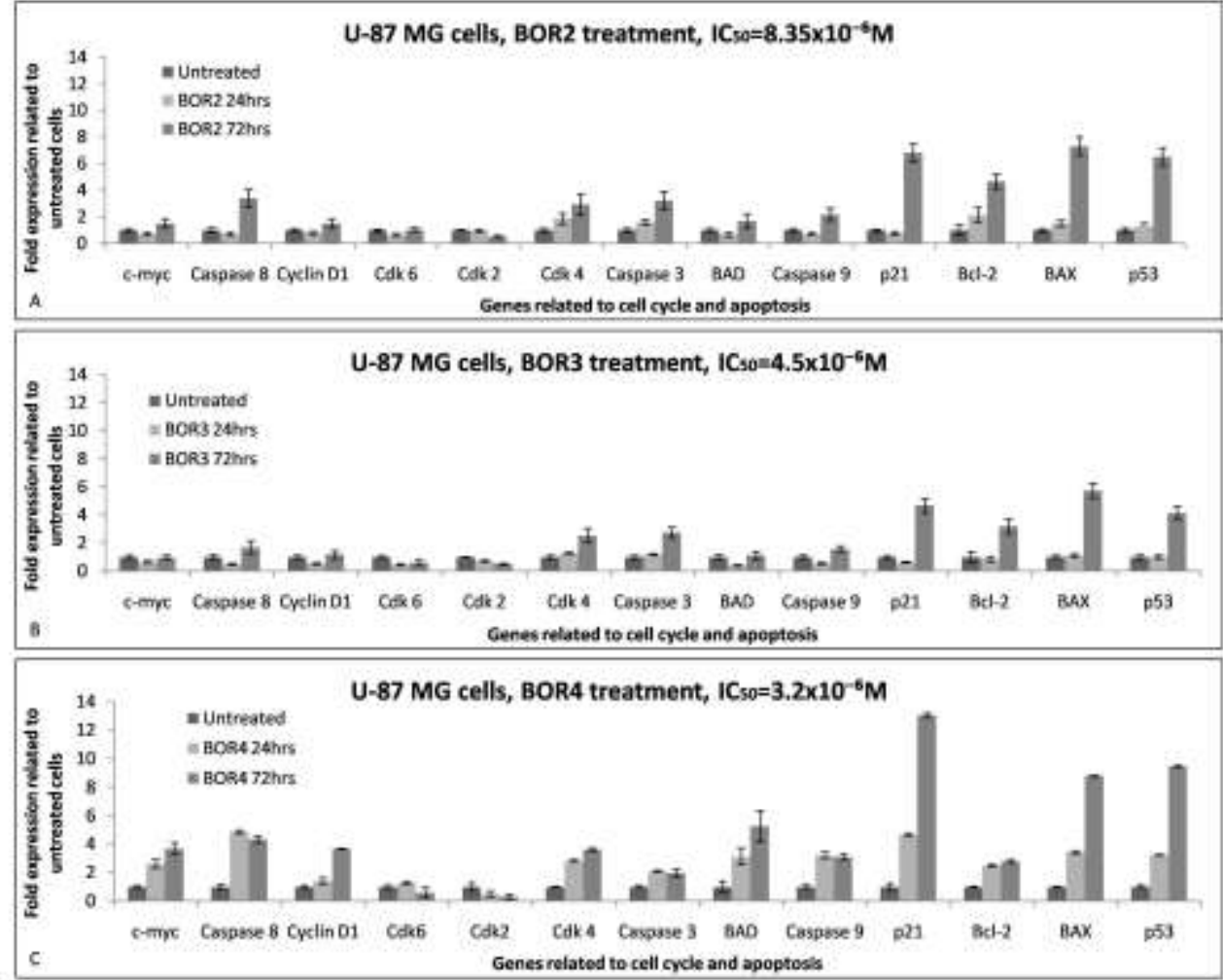

Figure 5 
Figure 6
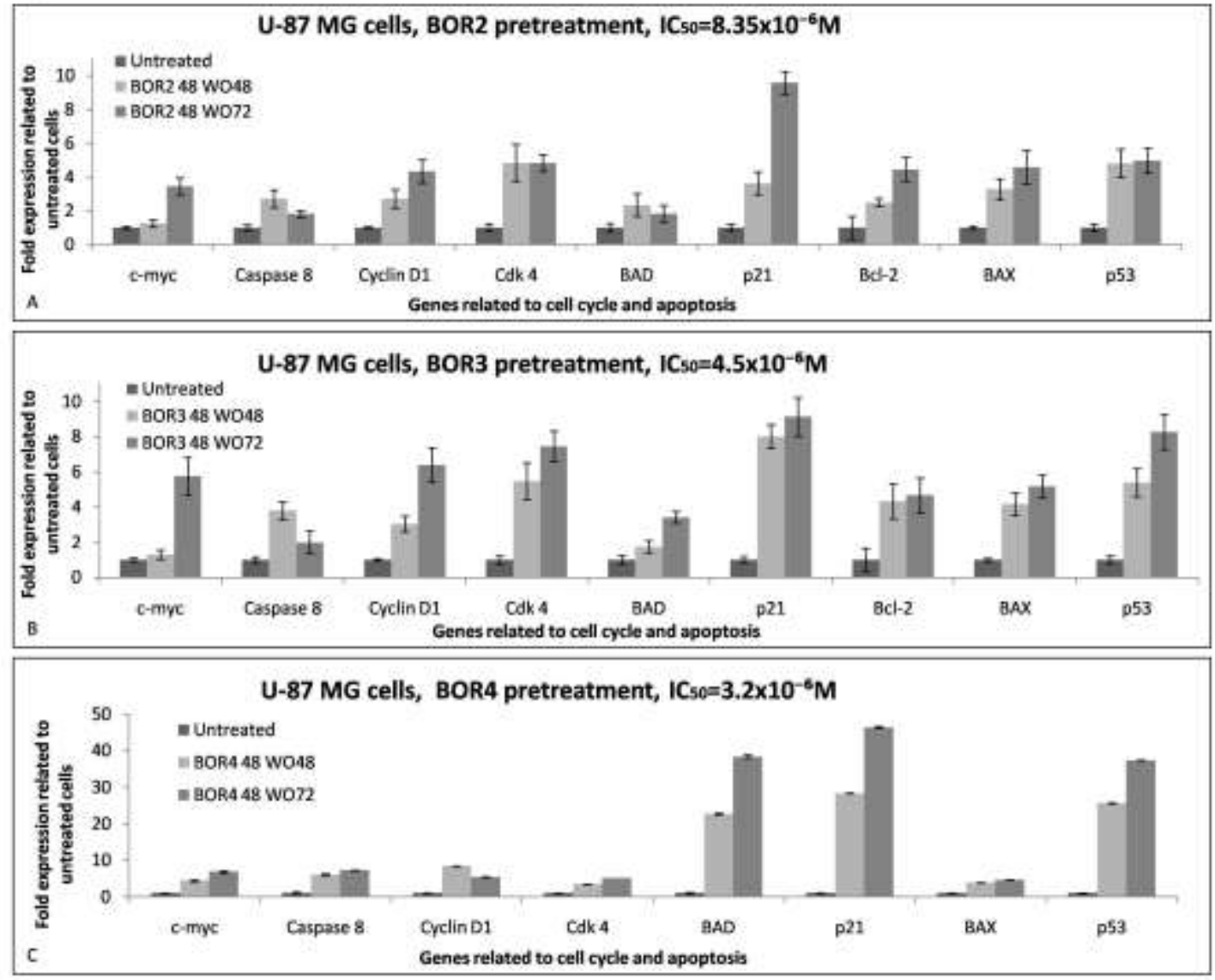

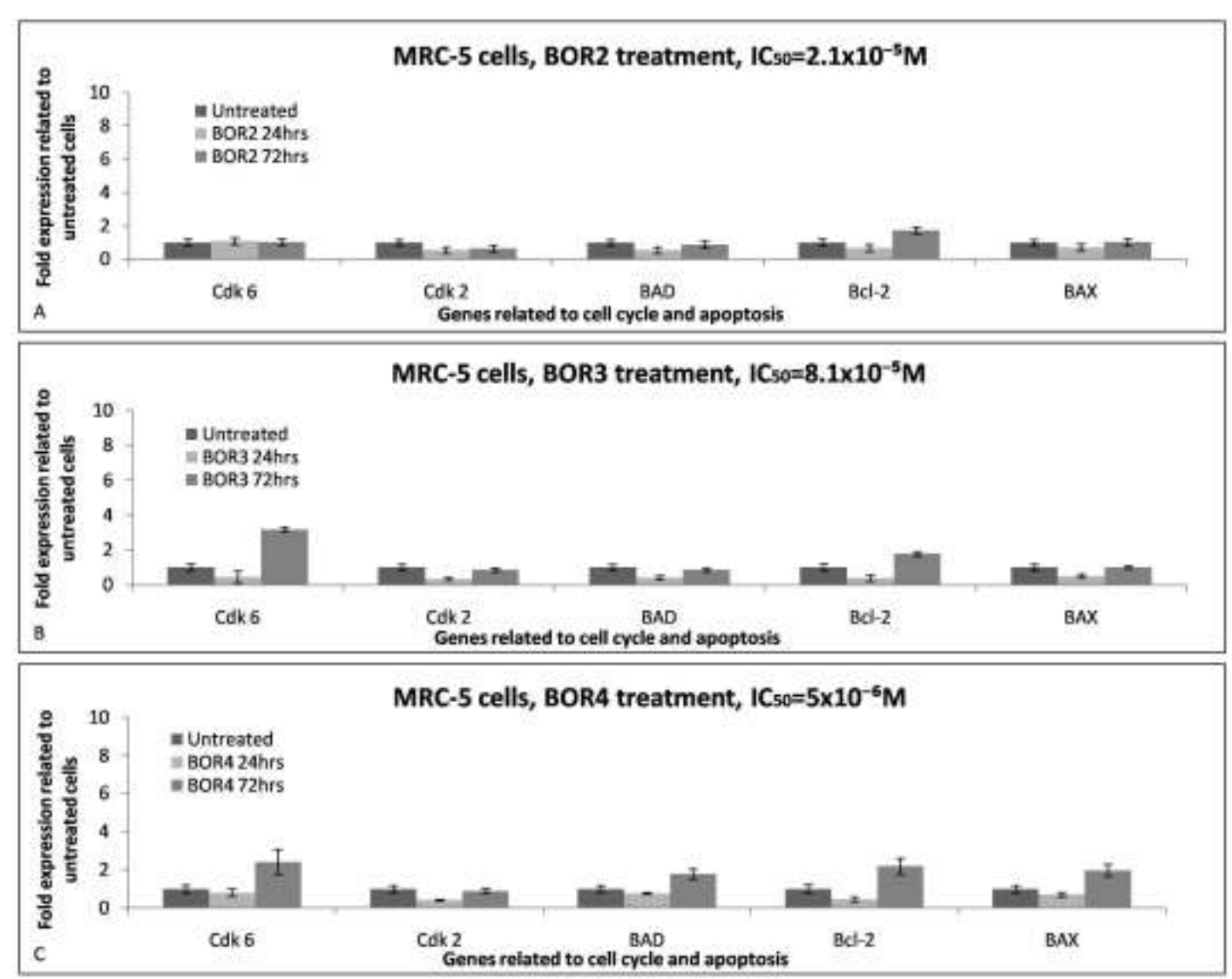

Figure 7 

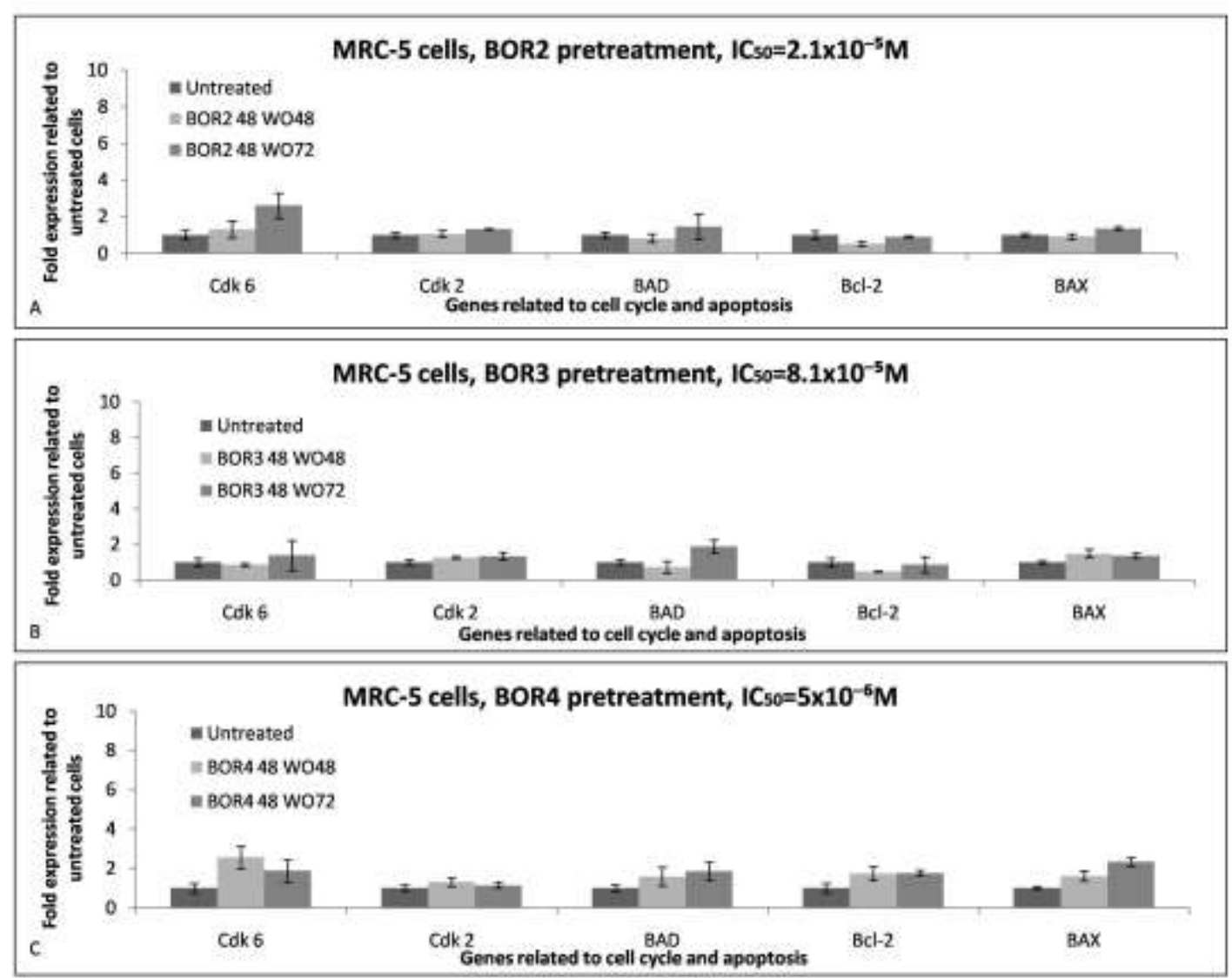

Figure 8 
Pharmacological development of target-specific delocalized lipophilic

cationfunctionalized

carboranes for cancer therapy

Eirini D. Tseligka,1 Aikaterini Rova,1 Elsa P. Amanatiadou,1 Gianpiero Calabrese,2

John Tsibouklis, 3 Dimitrios G. Fatouros,4 and Ioannis S. Vizirianakis1,5*

1Department of Pharmacology, School of Pharmacy, Aristotle University of

Thessaloniki, GR-54124 Thessaloniki, Greece

${ }_{2}$ School of Pharmacy and Chemistry, Kingston University, Kingston-upon Thames, KT1 2EE, UK

3School of Pharmacy and Biomedical Sciences, University of Portsmouth, Portsmouth, PO1 2DT, UK

4Department of Pharmaceutical Technology, School of Pharmacy, Aristotle

University of Thessaloniki, GR-54124 Thessaloniki, Greece

5Department of Life and Health Sciences, University of Nicosia, 1700 Nicosia,

Cyprus

*Corresponding author: Ioannis S. Vizirianakis, Ph.D., Department of Pharmacology, School of Pharmacy, Aristotle University of Thessaloniki, GR-54124 Thessaloniki, Greece. e-mail: ivizir@pharm.auth.gr 
Supplementary Table S1. Primer sequences used to analyze gene expression profiles by qPCR

\begin{tabular}{|c|c|c|c|}
\hline HGNC Gene & Primer code & Primer sequence & PCR product size \\
\hline \multirow{2}{*}{$\begin{array}{l}\text { MYC } \\
\text { (c-myc) }\end{array}$} & hCmyc RT F & 5'- AGGAGAATGTCAAGAGGCGA -3' & \multirow[t]{2}{*}{$119 b p$} \\
\hline & hCmyc RT R & 5'- GGCCTTTTCATTGTTTTTCCA -3' & \\
\hline \multirow{2}{*}{$\begin{array}{l}\text { CASP8 } \\
\text { (caspase 8) }\end{array}$} & hCasp8 RT F & 5'- GATGACATGAACCTGCTGGA-3' & \multirow[t]{2}{*}{$111 b p$} \\
\hline & hCasp8 RT R & 5'- CAGGCTCTTGTTGATTTGGG -3' & \\
\hline \multirow{2}{*}{$\begin{array}{l}\text { CCND1 } \\
\text { (cyclin D1) }\end{array}$} & hCyclD1 RT F & 5'- CTGCGAAGTGGAAACCATC -3' & \multirow[t]{2}{*}{ 117bp } \\
\hline & hCyclD1 RT R & 5'- TTGAAGTAGGACACCGAGGG -3' & \\
\hline \multirow{2}{*}{$\begin{array}{l}\text { CDK6 } \\
\text { (cdk6) }\end{array}$} & hCdk6 RT F & 5'- TGCACAGTGTCACGAACAGA -3' & \multirow[t]{2}{*}{ 150bp } \\
\hline & hCdk6 RT R & 5' ACCTCGGAGAAGCTGAAACA -3' & \\
\hline \multirow{2}{*}{$\begin{array}{l}C D K 2 \\
(c d k 2)\end{array}$} & hCdk2 RT F & 5'-TTGTCAAGCTGCTGGATGTC -3 & \multirow[t]{2}{*}{$126 b p$} \\
\hline & hCdk2 RT R & 5'- TGATGAGGGGAAGAGGAATG -3' & \\
\hline \multirow{2}{*}{$\begin{array}{l}C D K 4 \\
(c d k 4)\end{array}$} & hCdk4 RT F & 5-ACCAGATGGCACTTACACCC-3 & \multirow[t]{2}{*}{$148 \mathrm{bp}$} \\
\hline & hCdk4 RT R & 5'- CCACAGAAGAGAGGCTTTCG -3' & \\
\hline \multirow{2}{*}{$\begin{array}{l}\text { CASP3 } \\
\text { (caspase 3) }\end{array}$} & hCasp3 RT F & 5'-GGTTCATCCAGTCGCTTTGT -3' & \multirow[t]{2}{*}{ 100bp } \\
\hline & hCasp3 RT R & 5'- AATTCTGTTGCCACCTTTCG -3' & \\
\hline \multirow{2}{*}{$\begin{array}{l}B A D \\
\text { (bad) }\end{array}$} & hBAD RT F & 5'-CAGATCCCAGAGTTTGAGCC-3' & \multirow[t]{2}{*}{ 156bp } \\
\hline & hBAD RT R & 5'-CTGCTCCTGCTGGTGACTG-3' & \\
\hline \multirow{2}{*}{$\begin{array}{l}\text { CASP9) } \\
\text { (caspase 9) }\end{array}$} & hCasp9 RT F & 5'-TCGAAGCCAACCCTAGAAAA-3' & \multirow[t]{2}{*}{$110 \mathrm{bp}$} \\
\hline & hCasp9 RT R & 5'- CCTCCAGAACCAATGTCCAC-3' & \\
\hline \multirow{2}{*}{$\begin{array}{l}\text { CDKN1A } \\
(p 21)\end{array}$} & hp21 RT F & 5'- GAGCGATGGAACTTCGACTT -3' & \multirow[t]{2}{*}{ 101bp } \\
\hline & hp21 RT R & 5'-GTGGGAAGGTAGAGCTTGGG -3' & \\
\hline \multirow{2}{*}{$\begin{array}{l}\text { BCL2 } \\
(b c l-2)\end{array}$} & hBcl2 RT F & 5'-ACTTCGCCGAGATGTCCA -3' & \multirow[t]{2}{*}{$123 b p$} \\
\hline & hBcl2 RT R & 5'-CAAAGAAGGCCACAATCCTC -3' & \\
\hline \multirow{2}{*}{$\begin{array}{l}B A X \\
\text { (bax) }\end{array}$} & hBAX RT F & 5'-TCTGACGGCAACTTCAACTG -3' & \multirow[t]{2}{*}{ 132bp } \\
\hline & hBAX RT R & 5'-GAGGAAGTCCAATGTCCAGC -3' & \\
\hline \multirow{2}{*}{$\begin{array}{l}\text { TP53 } \\
(p 53)\end{array}$} & p53 F & 5'- CCTTCCCAGAAAACCTACCAG-3' & \multirow[t]{2}{*}{$230 b p$} \\
\hline & p53 R & 5'- CCTCACAACCTCCGTCATG-3' & \\
\hline \multirow{2}{*}{$\begin{array}{l}\text { ACTB } \\
\text { (actin, beta) }\end{array}$} & $\mathrm{b}$ - actin $\mathrm{hmF}$ & 5'-TTGCTGACAGGATGCAGAAG-3' & \multirow[t]{2}{*}{ 147bp } \\
\hline & b- actin hmR & 5'-TGATCCACATCTGCTGGAAG-3' & \\
\hline
\end{tabular}




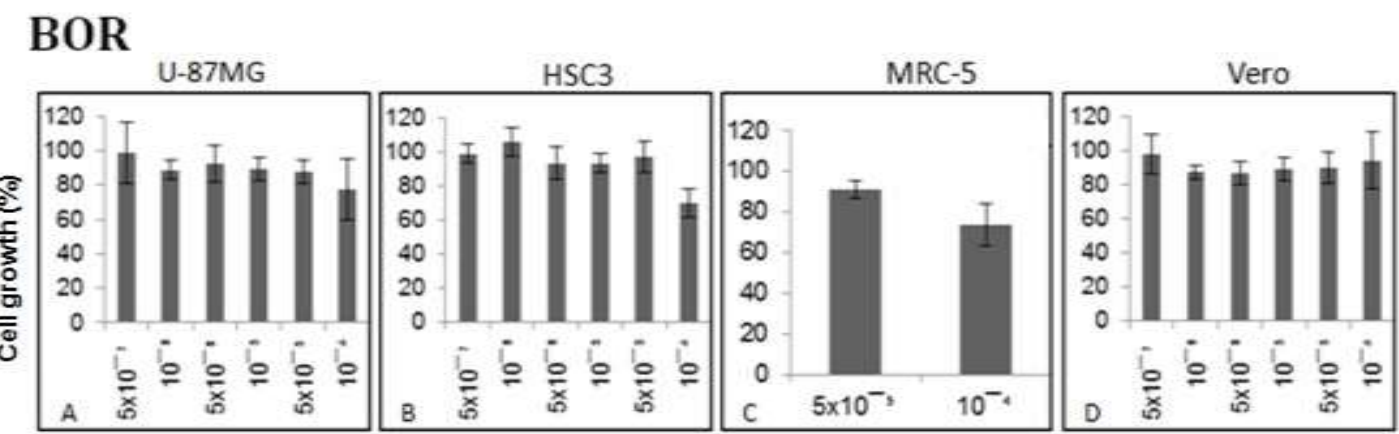

Concentration (M)

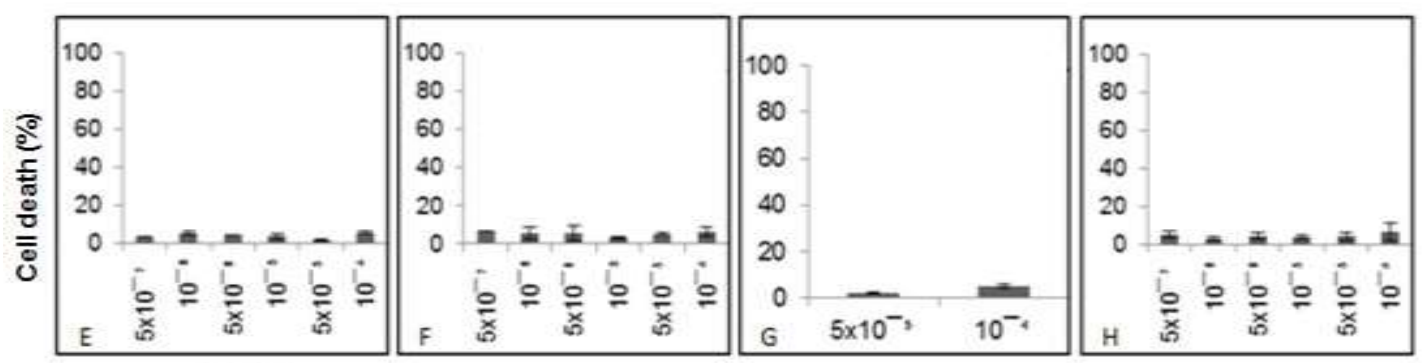

Concentration (M)

Supplementary Figure S1. Assessment of the cell growth and the proportion of dead cells in cultures of malignant (U-87MG, HSC-3) and normal (MRC-5 and Vero) cell lines grown in culture at various concentrations of compound BOR. The measurements were carried out as described under "Experimental section".

BOR2

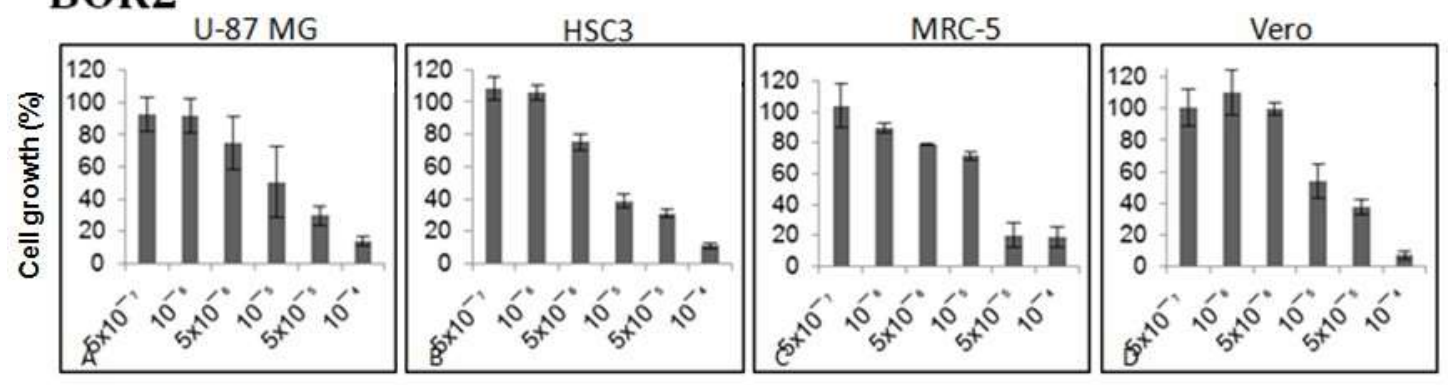

Concentration (M)
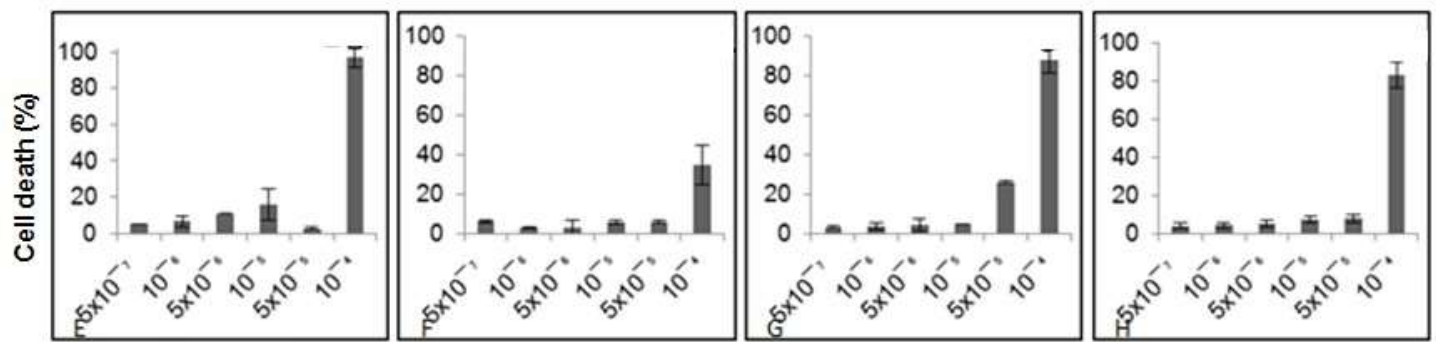

Concentration (M)

Supplementary Figure S2. The Assessment of the cell growth and the proportion of dead cells in cultures of malignant (U-87MG, HSC-3) and normal (MRC-5 and Vero) cell lines grown in culture at various concentrations of compound BOR2. The measurements were carried out as described under "Experimental section". 


\section{BOR3}

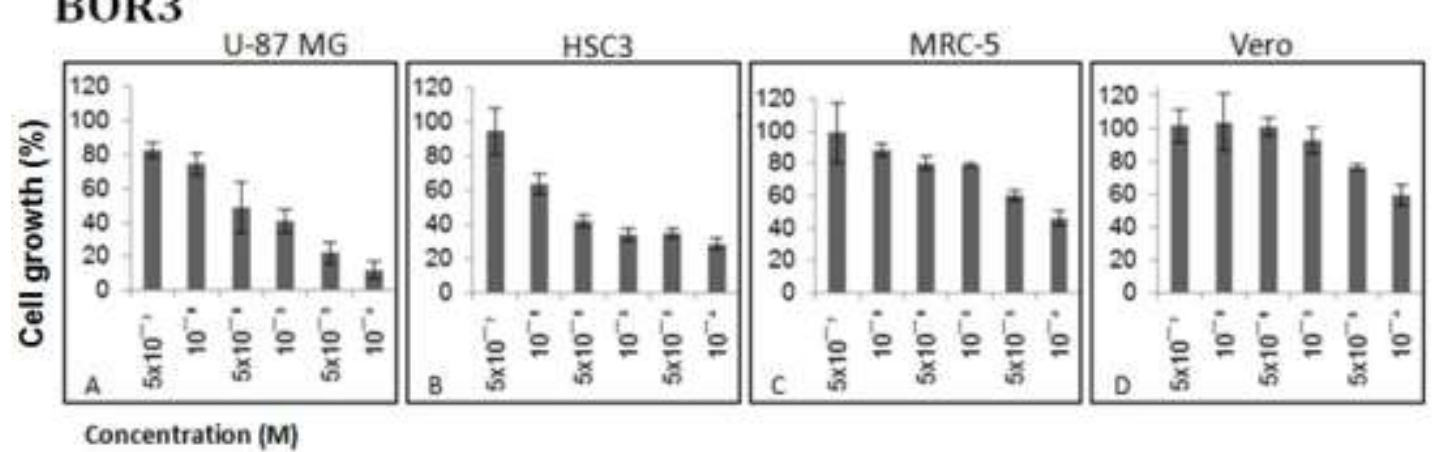

Concentration (M)

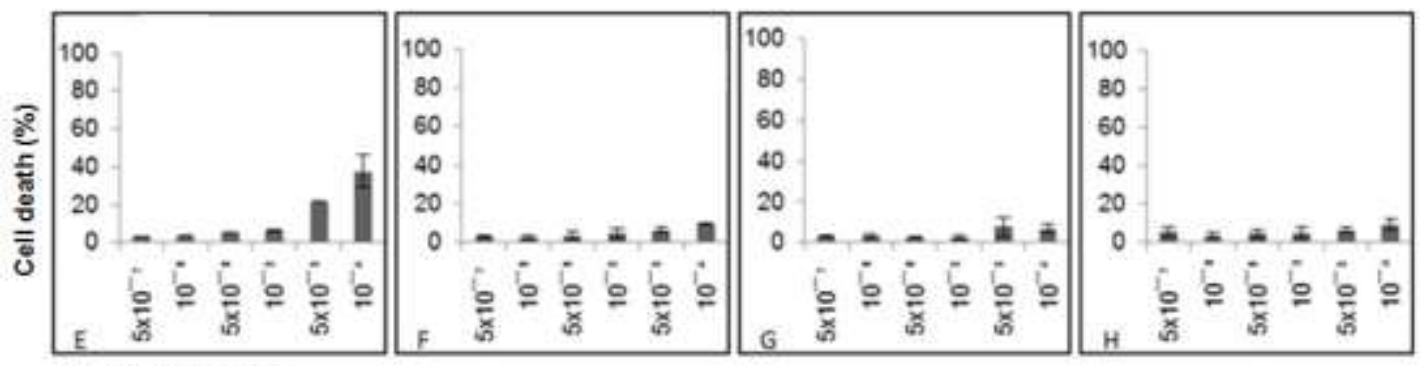

Concentration (M)

Supplementary Figure S3. Assessment of the cell growth and the proportion of dead cells in cultures of malignant (U-87MG, HSC-3) and normal (MRC-5 and Vero) cell lines grown in culture at various concentrations of compound BOR3. The measurements were carried out as described under "Experimental section".

BOR4

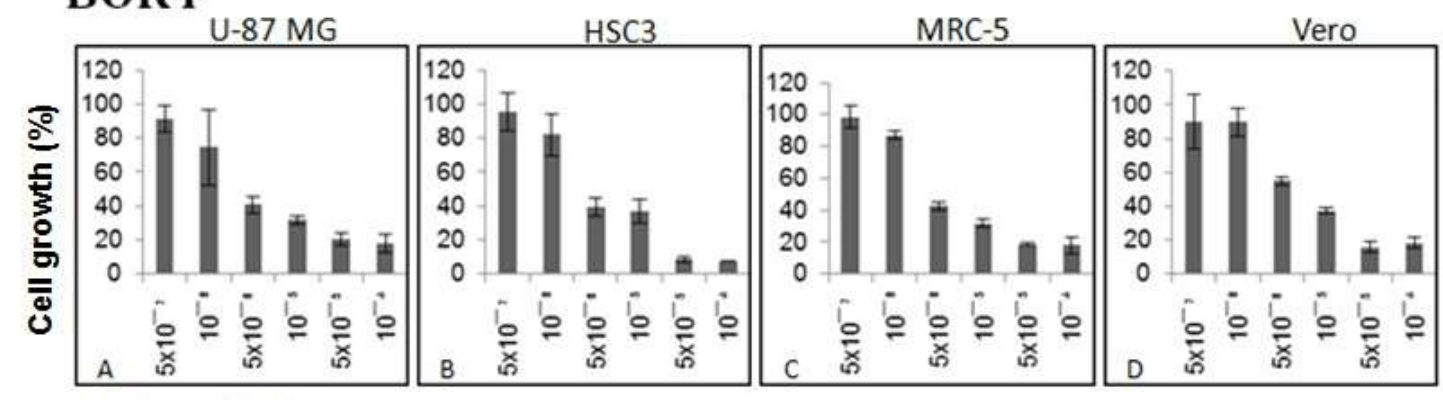

Concentration (M)

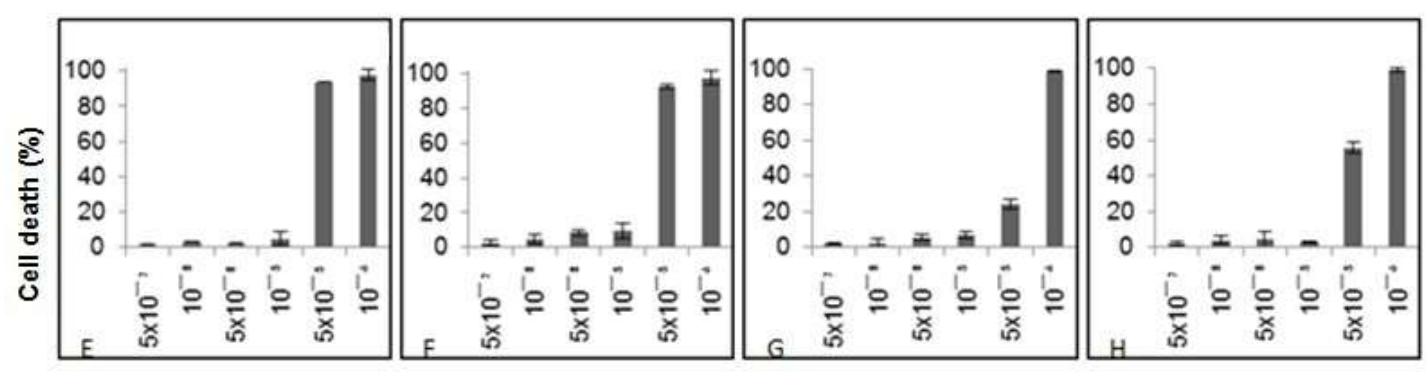

Concentration (M)

Supplementary Figure S4. Assessment of the cell growth and the proportion of dead cells in cultures of malignant (U-87MG, HSC-3) and normal (MRC-5 and Vero) cell 
lines grown in culture at various concentrations of compound BOR4. The measurements were carried out as described under "Experimental section".

6

\section{BOR5}

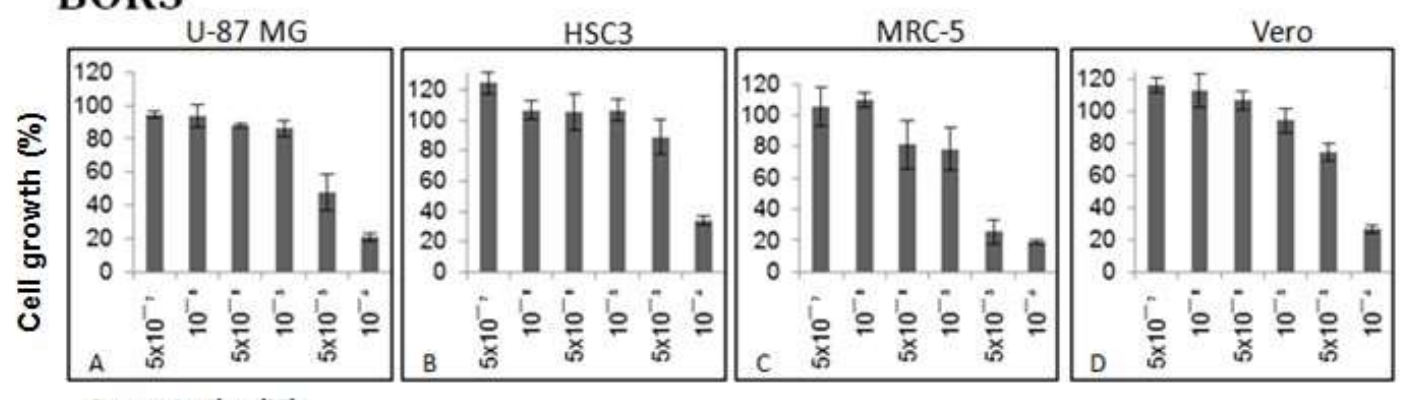

Concentration (M)

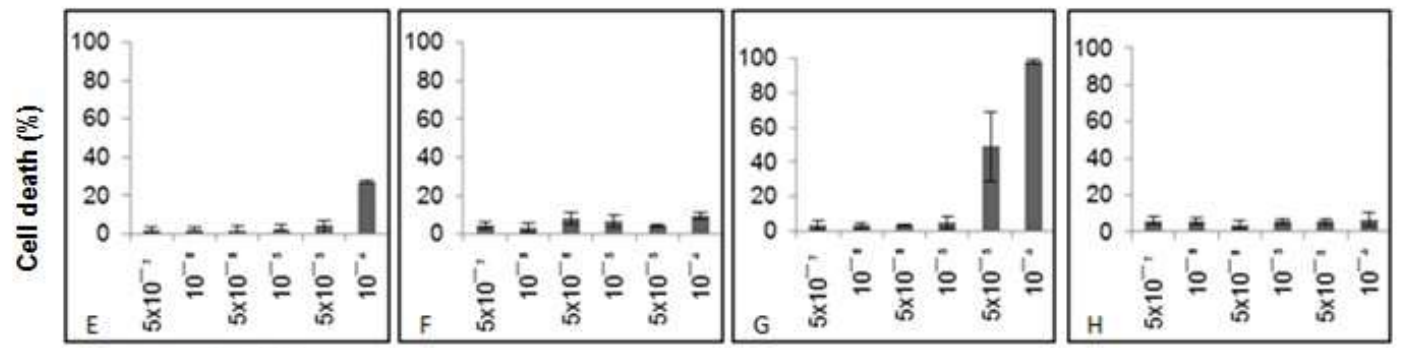

Concentration (M)

Supplementary Figure S5. Assessment of the cell growth and the proportion of dead cells in cultures of malignant (U-87MG, HSC-3) and normal (MRC-5 and Vero) cell lines grown in culture at various concentrations of compound BOR5. The measurements were carried out as described under "Experimental section". 

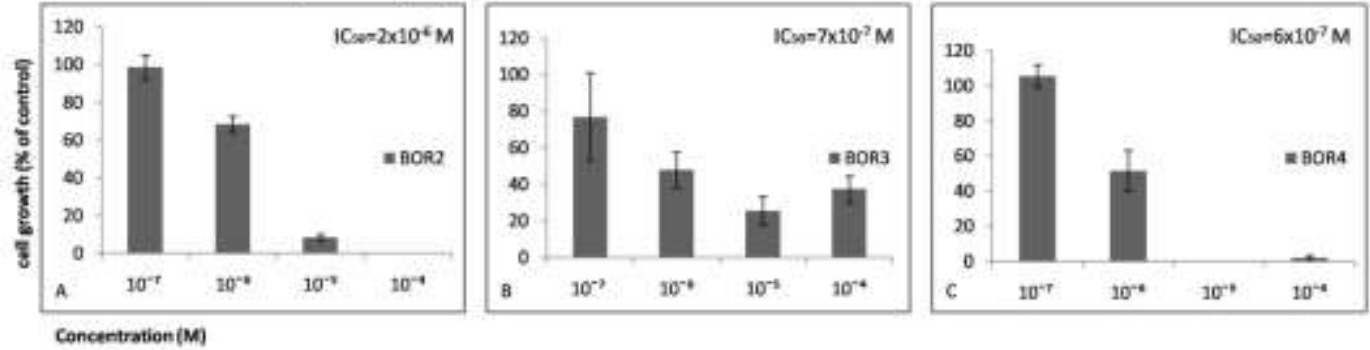

EGFR $^{\text {pos }}$ cells (neurospheres)
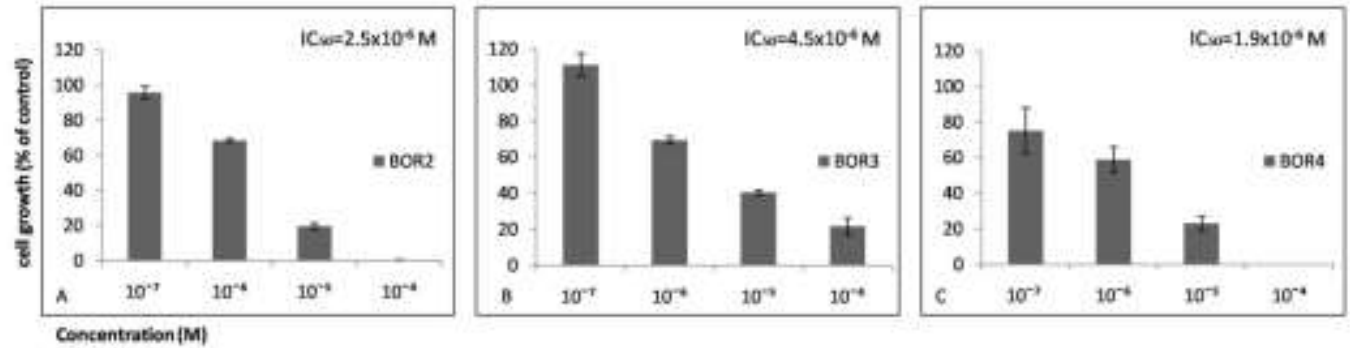

Supplementary Figure S6. Cytotoxicity assessment of DLC-carboranes in primary GBM CSCs growing either as monolayers or as neurospheres.

Upper panels: The EGFR $^{\text {neg }}$ primary GBM CSCs, which grow in culture as monolayers, were treated at specified concentrations of BOR2, BOR3 and BOR4 for $48 \mathrm{~h}$. Cell proliferation was assessed by the MTT assay, as described under "Experimental section". The data shown represent the mean values $( \pm \mathrm{SD})$ of three independent experiments. Statistics was carried out by paired t-test. A significance level of $\mathrm{p}<0.05$ denoted significance. Lower panels: The EGFR ${ }^{\text {pos }}$ primary GBM CSCs, which grow in culture as neurospheres, were exposed for $48 \mathrm{~h}$ to the specified concentrations of BOR2, BOR3 and BOR4. Cell proliferation was assessed by means of the MTT assay, as described under Materials and Methods. The data shown represent the mean values $( \pm \mathrm{SD})$ of three independent experiments. Statistical analysis was performed by paired t-test. A significance level of $\mathrm{p}<0.05$ denoted significance. 

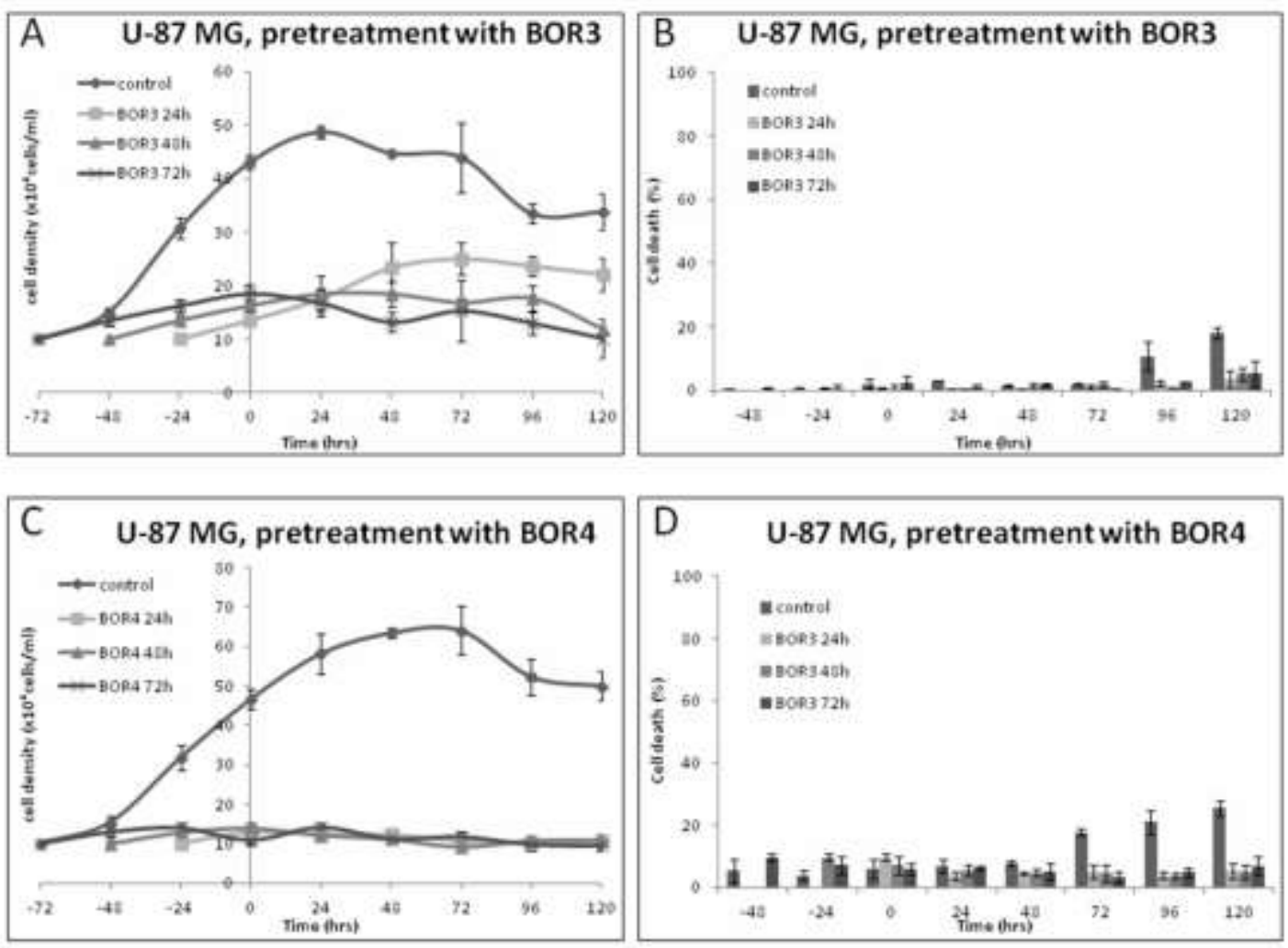

Supplementary Figure S7. Assessment of cell proliferation potential of U-87 MG cells in culture following their pretreatment with BOR3 and BOR4. Malignant human U-87 MG cells that had been grown in culture were treated with the $\mathrm{IC}_{50}$ concentration of BOR3 $\left(4.5 \times 10^{-6} \mathrm{M}\right.$; panels A and B) and/or of BOR4 $\left(3.2 \times 10^{-6} \mathrm{M}\right.$; panels $\mathrm{C}$ and D) at time intervals (-24, $-48-72 \mathrm{~h}$; pretreatment). After this time, cells were washed out (time 0) and allowed to grow in culture in agent-free medium. Cell growth (Panels A and C) and cell death (Panels B and D) were assessed, as described under "Materials and Methods". The data shown above indicate a representative experiment where three independent measurements were used to calculate the mean $( \pm \mathrm{SD})$. A biological replication of this experiment was carried out twice with similar results. Statistics was performed by paired t-test. A significance level of $p<0.05$ denoted significance. 

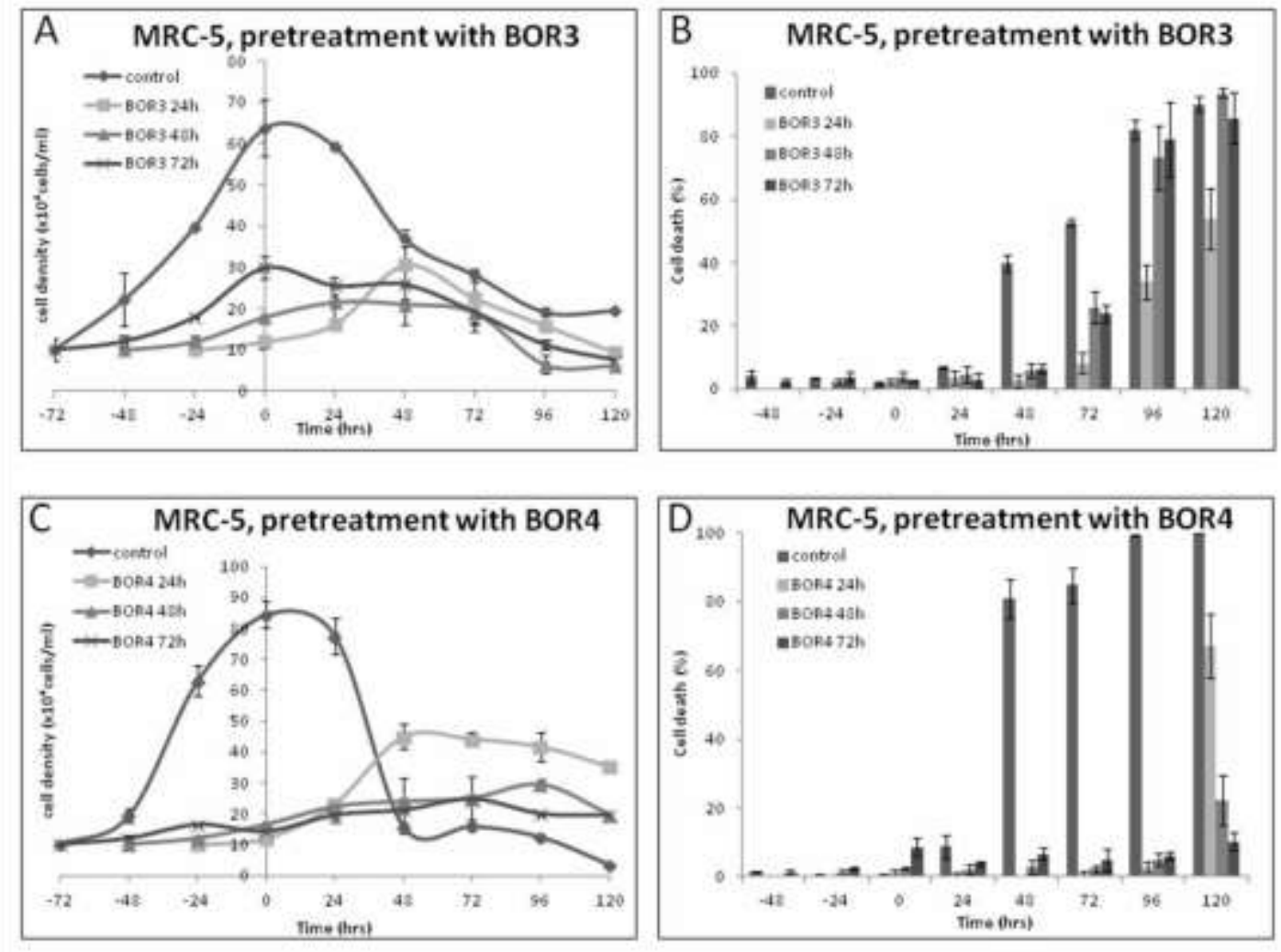

Supplementary Figure S8. Assessment of cell proliferation potential of MRC-5 cells in culture following their pretreatment with BOR3 and

BOR4. Normal human MRC-5 cells that had been grown in culture were treated with the $\mathrm{IC}_{50}$ concentration of BOR3 $\left(8.1 \times 10^{-5} \mathrm{M}\right.$; panels A and B) and/or of BOR4 $\left(5 \times 10^{-6}\right.$ M;

panels $\mathrm{C}$ and $\mathrm{D})$ at time intervals $(-24,-48-72 \mathrm{~h}$; pretreatment). Afterwards, cells were washed out (time 0) and allowed to grow in culture in agent-free medium. Cell growth (Panels A and C) and cell death (Panels B and D) were assessed as described under "Materials and Methods". The data shown above indicate a representative experiment where three independent measurements were used to calculate the mean $( \pm \mathrm{SD})$. A biological replication of this experiment was carried out twice with similar results. Statistics was performed by paired t-test. A significance level of $p<0.05$ denoted significance. 
